Review Article

\title{
Scientific Evidence of Rice By-Products for Cancer Prevention: Chemopreventive Properties of Waste Products from Rice Milling on Carcinogenesis In Vitro and In Vivo
}

\author{
Bee Ling $\operatorname{Tan}^{1}$ and Mohd Esa Norhaizan ${ }^{1,2,3}$ \\ ${ }^{1}$ Department of Nutrition and Dietetics, Faculty of Medicine and Health Sciences, Universiti Putra Malaysia, 43400 Serdang, \\ Selangor, Malaysia \\ ${ }^{2}$ Research Centre of Excellent, Nutrition and Non-Communicable Diseases (NNCD), Faculty of Medicine and Health Sciences, \\ Universiti Putra Malaysia, 43400 Serdang, Selangor, Malaysia \\ ${ }^{3}$ Laboratory of Molecular Biomedicine, Institute of Bioscience, Universiti Putra Malaysia, 43400 Serdang, Selangor, Malaysia
}

Correspondence should be addressed to Mohd Esa Norhaizan; nhaizan@upm.edu.my

Received 14 October 2016; Revised 1 December 2016; Accepted 4 December 2016; Published 22 January 2017

Academic Editor: Sung-Hoon Kim

Copyright (C) 2017 Bee Ling Tan and Mohd Esa Norhaizan. This is an open access article distributed under the Creative Commons Attribution License, which permits unrestricted use, distribution, and reproduction in any medium, provided the original work is properly cited.

Cancer is a significant global health concern affecting men and women worldwide. Although current chemopreventive drugs could inhibit the growth of cancer cells, they exert many adverse side effects. Dietary factor plays a crucial role in the management of cancers and has drawn the attention of researchers to be used as an option to combat this disease. Both in vitro and in vivo studies showed that rice and its by-products display encouraging results in the prevention of this disease. The mechanism of anticancer effect is suggested partly through potentiation of bioactive compounds like vitamin E, phytic acid, $\gamma$-aminobutyric acid (GABA), $\gamma$-oryzanol, and phenolics. Nevertheless, the bioactivity of rice and its by-products is still incompletely understood. In this review, we present the findings from a preclinical study both in in vitro and in animal experiments on the promising role of rice by-products with focus on cancer prevention.

\section{Introduction}

Cancer is a significant health concern. One in eight deaths worldwide is due to cancer [1]. It represents the first or second cause of death in advanced countries. Therefore, urgent action is warranted to reduce the threats of this disease, particularly in developing countries in which the prevalence and incidence of this disease are expected to increase. Genetic defects only account for nearly $5-10 \%$ of all cancer cases, whereas $90-95 \%$ are due to the environment and lifestyle [2]. Therefore, most of the cancer cases and deaths worldwide are actually preventable [3]. It has also been reported that up to $30 \%$ of human cancers could be prevented via an appropriate dietary modification [4].

Carcinogenesis is a complex multistage process comprised of initiation, promotion, and progression stage. Cancer chemoprevention involves the use of natural, synthetic, or biological agents to delay, inhibit, or prevent the initial phases of carcinogenesis, as well as the progression of premalignant cells to invasive disease [5]. In chemoprevention, a vital goal is to block tumor progression [6]. In developed countries, chemopreventive drugs, such as celecoxib and tamoxifen, are being used in high-risk populations; however, due to their adverse side effects, these drugs are not feasible in the developing countries [7-9].

Extensive studies in the past few decades have shown that there are varieties of dietary and botanical natural compounds with chemopreventive properties including garlic, green tea, soy, apple, olive oil, and grape [11-13]. Several recent studies also reported that natural products play a critical role against cancer [14-16]. Identification of bioactive compounds which have medicinal properties from natural products or by-products may promote the nutraceuticals as an inexpensive alternative to anticancer drug therapies 
TABLE 1: Production, area harvested, and yield of paddy [10].

\begin{tabular}{|c|c|c|c|c|c|c|}
\hline \multirow[b]{2}{*}{ Regions } & \multicolumn{3}{|c|}{2013} & \multicolumn{3}{|c|}{2003} \\
\hline & $\begin{array}{l}\text { Area harvested } \\
\qquad(\mathrm{Ha})\end{array}$ & $\begin{array}{c}\text { Production } \\
\text { quantity (tons) }\end{array}$ & $\begin{array}{c}\text { Yield } \\
(\mathrm{Hg} / \mathrm{Ha})\end{array}$ & $\begin{array}{c}\text { Area harvested } \\
(\mathrm{Ha})\end{array}$ & $\begin{array}{c}\text { Production } \\
\text { quantity (tons) }\end{array}$ & $\begin{array}{c}\text { Yield } \\
(\mathrm{Hg} / \mathrm{Ha})\end{array}$ \\
\hline China & 30486000 & 205015000 & 67249 & 26780124 & 162304280 & 60606 \\
\hline India & 43500000 & 159200000 & 36598 & 42592500 & 132789000 & 31177 \\
\hline Indonesia & 13835252 & 71279709 & 51520 & 11477357 & 52137600 & 45426 \\
\hline Thailand & 12373163 & 38787697 & 31348 & 10163878 & 29473521 & 28998 \\
\hline Vietnam & 7902808 & 44039291 & 55726 & 7452200 & 34568800 & 46387 \\
\hline Malaysia & 688207 & 2626881 & 38170 & 671800 & 2257000 & 33596 \\
\hline
\end{tabular}

Ha: hectares; Hg/Ha: hectogram/hectare.

which are toxic, immune-suppressive, mutagenic, and even carcinogenic $[17,18]$; besides, major treatment modalities include surgery, immunotherapy, and radiotherapy [19-21]. Natural products and their compounds may act as a modulator of antitumorigenicity either as separate entities or by serving in synergism [22]. The combination of two or more components in drug design has also been proven to have clinically synergistic benefits against cancer treatment [23].

In this review, we present the findings from a preclinical study both in vitro and in vivo on the promising role of rice by-products with focus on cancer perspective.

\section{Production of Rice By-Products}

High demands of crop production in the world are primarily due to the three key forces which are increasing human population, meat and dairy consumption from growing affluence, and biofuel consumption [24-27]. Thus, global agricultural production is projected to increase by $60-110 \%$ by 2050 to meet the increasing demands $[26,28,29]$ and provide food security to nearly 870 million chronically undernourished individuals [30].

Rice areas with doubling yield rates are only observed in several local areas within Afghanistan, India, Bangladesh, Laos, Vietnam, and Cambodia. In contrast, a significant reduction in the rates of rice yield is reported in some parts of India (particularly in Uttar Pradesh, Maharashtra, and Tamil Nadu) and in North Korea. Rice provides approximately $30 \%$ and $27 \%$ as a source of energy in India and China, respectively. The world's third largest rice producer, Indonesia, produces about $49 \%$ of energy, in which the yield improvement rates are slightly lower at $0.4 \%$ per year [32]. The production, area harvested, and yield of paddy in several countries are shown in Table 1.

Rice (Oryza sativa) is a staple food of dietary calories for half of the humanity and has been widely demonstrated as a chemopreventive component [33]. The rice milling process is comprised of two basic stages: first is to remove the husk to produce brown rice and the other is to remove the bran layer from brown rice to produce the polished (or white) rice. Additionally, the milling process also separates the germ and some of the endosperm as broken kernels and powdery materials [34]. Therefore, the output of a rice milling process consists of a main product, which is milled rice, and

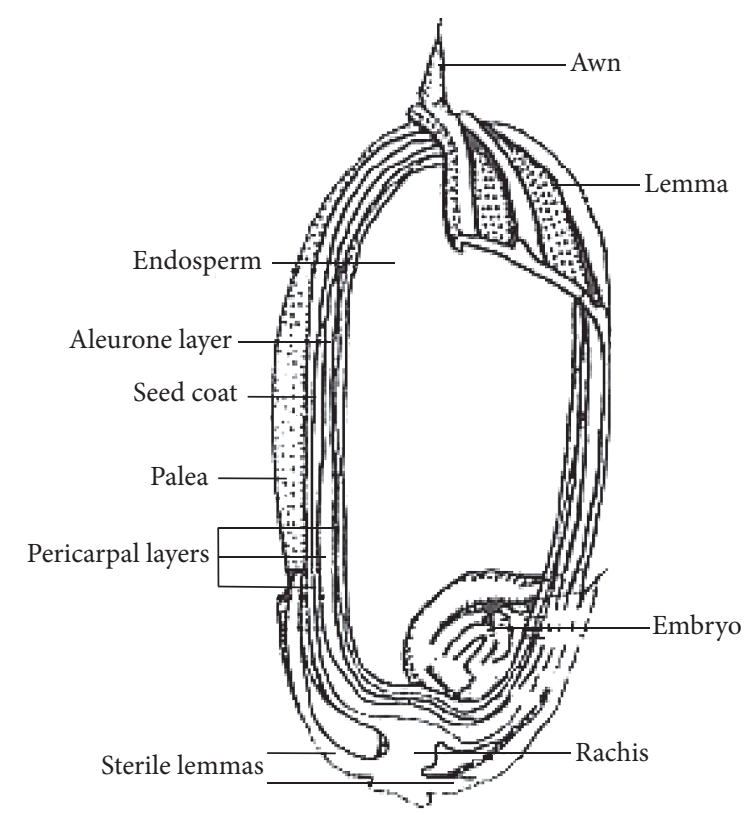

FIgURE 1: Structure of rice grain [31].

several rice by-products such as the husk, germ, bran layer, and broken kernels [35]. Traditionally, rice is consumed as polished white rice with the removal of husk, bran, and germ fractions [36], but currently the consumption of brown rice or germinated brown rice is getting popular due to more people becoming aware about their health. The production of rice by-product in rice processing was previously described by Esa et al. [37]. Structure of rice grain is shown in Figure 1.

\section{Nutrient Composition and Phytonutrients Properties of Rice By-Products}

High intake of whole grain food has been suggested as an indicator of the reduction of risk in several digestive tract neoplasms, such as stomach, colon, and gall bladder [59]. In an earlier study, Deng et al. [60] studied the health beneficial components in pigmented rice such as flavones, tannins, phenolics, sterols, tocols, $\gamma$-oryzanols, amino acids, 
TABLE 2: Proximate composition and minerals contents (\% of dry matter) of rice by-products.

\begin{tabular}{|c|c|c|c|c|c|c|}
\hline Nutrients & Broken $^{a}$ & Husk $^{\mathrm{b}}$ & $\operatorname{Bran}^{\mathrm{c}}$ & Polishings $^{\mathrm{d}}$ & Straw $^{\mathrm{e}}$ & Brewers' rice $^{f}$ \\
\hline Dry matter & $87.0-89.0$ & $87.0-92.5$ & $89-94$ & 90.0 & 90.9 & - \\
\hline Protein ${ }^{g}$ & $6.7-9.8$ & $2.1-4.3$ & $10.6-16.9$ & $11.2-13.4$ & $1.2-7.5$ & $9.01 \pm 0.27$ \\
\hline Crude fat & $0.5-1.9$ & $0.30-0.93$ & $5.1-19.7$ & $10.1-13.9$ & $0.8-2.1$ & $1.95 \pm 0.11$ \\
\hline Crude fiber & 0.6 & $30.0-53.4$ & $7.0-18.9$ & $2.3-3.6$ & $33.5-68.9$ & - \\
\hline Ash & 5.0 & $13.2-24.4$ & $8.8-28.8$ & $5.2-8.3$ & $12.2-21.4$ & $1.56 \pm 0.26$ \\
\hline Carbohydrate & - & $22.4-35.3$ & 90.0 & $51.1-55.0$ & $39.1-47.3$ & $72.42 \pm 1.25$ \\
\hline Calcium & $0.09-0.19$ & $0.04-0.21$ & $0.08-1.4$ & 0.05 & $0.30-0.71$ & $0.013 \pm 0.0016$ \\
\hline Phosphorus & $0.03-0.04$ & $0.07-0.08$ & $1.3-2.9$ & 1.48 & $0.06-0.16$ & $0.316 \pm 0.028$ \\
\hline
\end{tabular}

${ }^{\mathrm{a}}[38-42]$.

$\mathrm{b}[38,39,43-48]$.

${ }^{\mathrm{c}}[38-40,42-50]$.

$\mathrm{d}_{[41,42,48] \text {. }}$

e $[44,45,51-54]$

$\mathrm{f}[55]$.

${ }^{g}$ Animal scientists commonly use a conversion factor of $N \times 6.25$ for crude protein [56].

TABLE 3: Dietary fiber in rice husk, rice bran fiber, and rice straw.

\begin{tabular}{lccc}
\hline & Rice husk $^{\mathrm{a}}$ & Rice bran fiber & Rice straw $^{\mathrm{b}}$ \\
\hline Cellulose (\%) & 38.0 & 30.0 & 32.0 \\
$\begin{array}{l}\text { Hemicellulose } \\
\text { (\%) }\end{array}$ & 20.0 & 20.0 & 35.7 \\
Lignin (\%) & 22.0 & 20.0 & 22.3 \\
\hline a [57]. & & & \\
${ }^{\mathrm{b}}[58]$. & & &
\end{tabular}

$\gamma$-aminobutyric acid (GABA), and essential oils. These compounds have been shown to have a variety of bioactivities including antitumor, antioxidant, antiatherosclerosis, hypoglycemic, and antiallergic activities. The other components in whole grain such as indigestible fibers (Tables 2 and 3), as well as other phytochemicals as illustrated in Tables 4 and 5, have also been considered to contribute to the beneficial effects of whole grain [61].

Rice bran has been extensively studied among all rice by-products. Besides containing high amounts of vitamins, minerals, and fiber, rice bran also is rich in numerous bioactive components which draw a great deal of attention in the prevention and treatment of several types of human cancers. These bioactive components were reported to have antioxidant activities that can be directly associated with their anticancer effects [62] including leukemia, breast, lung, liver, cervical, stomach, and colorectal cancers [33, 63]. Studies by Moldenhauer et al. [64], Renuka Devi and Arumughan [65], and Canan et al. [66] further supported the role of a unique complex of naturally antioxidant compounds in rice bran to fight several diseases including cancer.

In addition to the rice bran, more than 1 million tons of rice husks is produced annually in rice processing in South Korea. Rice husk consists of $20 \%$ of the rice grain kernel and is nearly similar to other plant biomasses, containing a high proportion of organic substances [75]. Rice husk is inedible, which is utilized in many nonfood applications as low-value agricultural waste product. However, it was reported that rice husk is a valuable source of bioactive compounds that contained a high antioxidant property. Rice husk contained phenolic acids, which are a valuable source of natural antioxidants and prevent the rice seed from oxidative stress [70]. Thus, it has been recognized as a potential source of energy and organic chemicals [76, 77]. Hydrothermal treatments of rice husks also produce lignin-derived components such as caffeic acid and ferulic acid [78], which are crucial constituents for pharmaceutical application because they provide protection against photooxidative damage [79]. Rice husk has also been reported to have fatty acids, including linoleic, stearic, oleic, and palmitic acids [78]. Phenolic compounds in the methanolic extract of rice husk also displayed a high antioxidant activity against scavengers of singlet oxygen and suppressed high hydrogen peroxide-induced damage against cellular deoxynucleic acid (DNA) in human lymphocytes [80].

Rice germ is also a by-product from rice processing which is known as embryo or reproductive proportions which germinate and grow into a plant [57]. The amount of vitamin $\mathrm{E}$ in rice germ is 5 times higher compared with that of rice bran. Most of the vitamin E in rice germ is $\alpha$-tocopherol, which is the major active form of vitamin $\mathrm{E}$, while, for rice bran, most of the vitamin $\mathrm{E}$ is $\gamma$-tocopherol. Additionally, rice germ also comprised a substantial amount of vitamins $\left(B_{1}\right.$, $\mathrm{B}_{2}$, and $\mathrm{B}_{6}$ ), dietary fiber, and neurotransmitter GABA, which is believed to contain numerous beneficial health effects like improving blood pressure, cognition, and blood glucose levels. The amount of $\gamma$-oryzanol in rice germ, however, was 5 times lower than that of rice bran [81].

In addition to the rice bran, rice husk, rice straw, and rice germ, brewers' rice is another by-product in the rice industry that has a significant nutritional value. Brewers' rice consists of a mixture of broken kernels with rice bran and rice germ, which is usually removed during the rice milling process [82]. Brewers' rice is typically used as an animal feed and brewing material [83]. The size of brewers' rice is less than one quarter of the full kernel of milled rice. It is the last and the smallest milling portion that is separated during the 
TABLE 4: Phytochemicals and antioxidant properties of rice by-products.

\begin{tabular}{|c|c|c|c|}
\hline $\begin{array}{l}\text { Phytochemicals } \\
\text { or antioxidant } \\
\text { properties }\end{array}$ & Rice bran & Rice husk & $\begin{array}{l}\text { Brewers' } \\
\text { rice }\end{array}$ \\
\hline \multirow{8}{*}{$\begin{array}{l}\text { Gamma- } \\
\text { oryzanol } \\
(\mathrm{mg} / \mathrm{g})\end{array}$} & Methanol extract of defatted rice bran $($ India $)=7.82^{\mathrm{a}}$ & \multirow{8}{*}{$\begin{array}{l}\text { Acetone extract } \\
\text { of Thai rice husk } \\
\text { variety (Khao } \\
\text { Dawk Mali 105) } \\
=0.06-0.16^{\mathrm{e}}\end{array}$} & \multirow{8}{*}{$14.20^{\mathrm{h}}$} \\
\hline & Methanol extract of rice bran from Thailand $=0.56-1.08^{\mathrm{b}}$ & & \\
\hline & $\begin{array}{l}\text { Ethanol extract of rice bran from Suphan Buri (Thailand) = } \\
9.81^{c}\end{array}$ & & \\
\hline & Methanol extract of Japonica rice bran $=9.8 \pm 0.4^{\mathrm{d}}$ & & \\
\hline & Ethyl acetate extract of Japonica rice bran $=13.8 \pm 0.9^{\mathrm{d}}$ & & \\
\hline & Hexane extract of Japonica rice bran $=13.1 \pm 0.5^{\mathrm{d}}$ & & \\
\hline & $\begin{array}{l}\text { Acetone extract of Thai rice bran variety (Khao Dawk Mali } \\
105)=3.43-5.38^{\mathrm{e}}\end{array}$ & & \\
\hline & $80 \%$ methanol extract of whole rice bran $=0.93-5.13^{\mathrm{g}}$ & & \\
\hline \multirow{8}{*}{$\begin{array}{l}\text { Tocopherols } \\
(\mu \mathrm{g} / \mathrm{g})\end{array}$} & Methanol extract of defatted rice bran $($ India $)=138^{\mathrm{a}}$ & \multirow{8}{*}{$\begin{array}{l}\text { Acetone extract } \\
\text { of Thai rice husk } \\
\text { variety (Khao } \\
\text { Dawk Mali 105) } \\
=\text { not detected }^{\mathrm{e}}\end{array}$} & \multirow{8}{*}{$3.4^{\mathrm{h}}$} \\
\hline & Methanol extract of rice bran from Thailand $=350-670^{\mathrm{b}}$ & & \\
\hline & $\begin{array}{l}\text { Hexane extract of rice bran from Suphan Buri (Thailand) }= \\
172^{c}\end{array}$ & & \\
\hline & Methanol extract of Japonica rice bran $=573 \pm 13^{\mathrm{d}}$ & & \\
\hline & Ethyl acetate extract of Japonica rice bran $=770 \pm 24^{\mathrm{d}}$ & & \\
\hline & Hexane extract of Japonica rice bran $=196 \pm 24^{\mathrm{d}}$ & & \\
\hline & $\begin{array}{l}\text { Acetone extract of Thai rice bran variety (Khao Dawk Mali } \\
105)=70.67-87.54^{\mathrm{e}}\end{array}$ & & \\
\hline & $80 \%$ methanol extract of whole rice bran $=27.4-129.6^{\mathrm{g}}$ & & \\
\hline \multirow{5}{*}{$\begin{array}{l}\text { Tocotrienols } \\
(\mu \mathrm{g} / \mathrm{g})\end{array}$} & Methanol extract of rice bran from Thailand $=220-460^{b}$ & \multirow{5}{*}{-} & \multirow{5}{*}{$3.25^{\mathrm{h}}$} \\
\hline & Methanol extract of Japonica rice bran $=202 \pm 5^{\mathrm{d}}$ & & \\
\hline & Ethyl acetate extract of Japonica rice bran $=237 \pm 6^{\mathrm{d}}$ & & \\
\hline & Hexane extract of Japonica rice bran $=17 \pm 1^{\mathrm{d}}$ & & \\
\hline & $80 \%$ methanol extract of whole rice bran $=20.8-301.7^{\mathrm{g}}$ & & \\
\hline \multirow{3}{*}{$\begin{array}{l}\text { Total phenolic } \\
\text { content (g } \\
\text { GAE/kg) }\end{array}$} & Methanol extract of Japonica rice bran $=15.7 \pm 0.6^{\mathrm{d}}$ & \multirow{3}{*}{-} & \multirow{3}{*}{-} \\
\hline & Ethyl acetate extract of Japonica rice bran $=19.7 \pm 0.8^{\mathrm{d}}$ & & \\
\hline & Hexane extract of Japonica rice bran $=14.7 \pm 1.2^{\mathrm{d}}$ & & \\
\hline $\begin{array}{l}\text { Total } \\
\text { anthocyanins } \\
\text { (mg/g extract) }\end{array}$ & $70 \%$ ethanol extract of purple rice bran $=55.7 \pm 2.1^{\mathrm{f}}$ & - & - \\
\hline $\begin{array}{l}\text { Total proantho- } \\
\text { cyanidins (mg } \\
\text { pro. B2 equiv./g } \\
\text { extract) }\end{array}$ & $70 \%$ ethanol extract of red rice bran $=66.88 \pm 6.23^{\mathrm{f}}$ & - & - \\
\hline $\begin{array}{l}\text { Phytic acid } \\
(\mathrm{mg} / \mathrm{g})\end{array}$ & - & - & $0.38 \pm 0.01^{\mathrm{h}}$ \\
\hline
\end{tabular}

GAE: gallic acid equivalents.

a [65].

$\mathrm{b}[67]$.

${ }^{c}[68]$.

$\mathrm{d}[69]$.

e $[70]$.

${ }^{[}[63]$.

$\mathrm{g}[71]$.

$\mathrm{h}_{[72]}$.

milling of paddy rice and is usually removed from larger rice kernels [84]. Brewers' rice demonstrated high carbohydrate, protein, and fat contents [55]; minerals such as calcium, phosphorus, iron, sodium, and potassium; fatty acids such as linoleic acid, oleic acid, and palmitic acid. Brewers' rice also contained a variety of phytochemicals with chemopreventive properties including $\gamma$-oryzanol, phytic acid, vitamin E, phenolic antioxidants [72], and dietary fiber [55]. 
TABLE 5: Polyphenolic compounds present in the rice by-products.

\begin{tabular}{|c|c|c|c|}
\hline $\begin{array}{l}\text { Polyphenolic } \\
\text { compounds }\end{array}$ & Rice bran & Rice husk & Brewers' rice \\
\hline Gallic acid $(\mu \mathrm{g} / \mathrm{g})$ & - & $\begin{array}{l}80 \% \text { methanol extract }= \\
5.4-9.9^{\mathrm{a}}\end{array}$ & $\begin{array}{l}\text { Water extract } \\
=26.09 \pm 2.01^{\mathrm{d}}\end{array}$ \\
\hline $\begin{array}{l}\text { Protocatechuic } \\
\text { acid }(\mu \mathrm{g} / \mathrm{g})\end{array}$ & 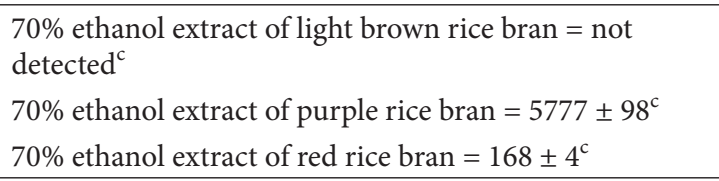 & $\begin{array}{l}80 \% \text { methanol extract }= \\
6.7-24.0^{\mathrm{a}}\end{array}$ & - \\
\hline $\begin{array}{l}\text { p-Hydroxybenzoic } \\
\text { acid }(\mu \mathrm{g} / \mathrm{g})\end{array}$ & (2) & $\begin{array}{l}80 \% \text { methanol extract }= \\
10.8-110.4^{\mathrm{a}}\end{array}$ & - \\
\hline $\begin{array}{l}\text { Chlorogenic acid } \\
(\mu \mathrm{g} / \mathrm{g})\end{array}$ & - & $\begin{array}{l}80 \% \text { methanol extract }= \\
4.8-11.3^{\mathrm{a}}\end{array}$ & - \\
\hline Vanillic acid $(\mu \mathrm{g} / \mathrm{g})$ & $\begin{array}{l}70 \% \text { ethanol extract of light brown rice bran }=34 \pm 2^{\mathrm{c}} \\
70 \% \text { ethanol extract of purple rice bran }=1568 \pm 36^{\mathrm{c}} \\
70 \% \text { ethanol extract of red rice bran }=72 \pm 3^{\mathrm{c}}\end{array}$ & $\begin{array}{l}80 \% \text { methanol extract }= \\
7.8-14.1^{\mathrm{a}} \\
80 \% \text { aqueous methanol }= \\
14.4-26.7^{\mathrm{b}}\end{array}$ & $\begin{array}{l}\text { Water extract } \\
=2.87 \pm 0.15^{\mathrm{d}}\end{array}$ \\
\hline $\begin{array}{l}\text { Syringic acid } \\
(\mu \mathrm{g} / \mathrm{g})\end{array}$ & - & $\begin{array}{l}80 \% \text { methanol extract }= \\
2.6-12.1^{\mathrm{a}}\end{array}$ & $\begin{array}{l}\text { Water extract } \\
=5.87 \pm 1.71^{\mathrm{d}}\end{array}$ \\
\hline $\begin{array}{l}\text { p-Coumaric acid } \\
(\mu \mathrm{g} / \mathrm{g})\end{array}$ & $\begin{array}{l}70 \% \text { ethanol extract of light brown rice bran }=424 \pm 1^{c} \\
70 \% \text { ethanol extract of purple rice bran }=517 \pm 49^{c} \\
70 \% \text { ethanol extract of red rice bran }=511 \pm 2^{c}\end{array}$ & $\begin{array}{l}80 \% \text { methanol extract }= \\
14.8-32.5^{\mathrm{a}} \\
80 \% \text { aqueous methanol }= \\
4.84-28.90^{\mathrm{b}}\end{array}$ & $\begin{array}{l}\text { Water extract } \\
=7.13 \pm 0.36^{\mathrm{d}}\end{array}$ \\
\hline Ferulic acid $(\mu \mathrm{g} / \mathrm{g})$ & $\begin{array}{l}80 \% \text { aqueous methanol }=20.70-33.45^{\mathrm{b}} \\
70 \% \text { ethanol extract of light brown rice bran }=1995 \pm 4^{\mathrm{c}} \\
70 \% \text { ethanol extract of purple rice bran }=1593 \pm 67^{\mathrm{c}} \\
70 \% \text { ethanol extract of red rice bran }=1055 \pm 11^{\mathrm{c}}\end{array}$ & $\begin{array}{l}80 \% \text { methanol extract }= \\
18.1-64.2^{\mathrm{a}}\end{array}$ & $\begin{array}{l}\text { Water extract } \\
=36.42 \pm 2.97^{\mathrm{d}}\end{array}$ \\
\hline $\begin{array}{l}\text { 4-Hydroxybenzoic } \\
\text { acid }(\mu \mathrm{g} / \mathrm{g})\end{array}$ & $\begin{array}{l}70 \% \text { ethanol extract of light brown rice bran }=673 \pm 10^{c} \\
70 \% \text { ethanol extract of purple rice bran }=\text { not detected } \\
70 \% \text { ethanol extract of red rice bran }=427 \pm 15^{c}\end{array}$ & - & - \\
\hline Caffeic acid ( $\mu \mathrm{g} / \mathrm{g})$ & $\begin{array}{l}70 \% \text { ethanol extract of light brown rice bran }=157 \pm 14^{\mathrm{c}} \\
70 \% \text { ethanol extract of purple rice bran }=\text { Not detected }^{\mathrm{c}} \\
70 \% \text { ethanol extract of red rice bran }=111 \pm 3^{\mathrm{c}}\end{array}$ & - & $\begin{array}{l}\text { Water extract } \\
=5.32 \pm 2.48^{\mathrm{d}}\end{array}$ \\
\hline Sinapic acid $(\mu \mathrm{g} / \mathrm{g})$ & $\begin{array}{l}70 \% \text { ethanol extract of light brown rice bran }= \\
2544 \pm 17^{\mathrm{c}} \\
70 \% \text { ethanol extract of purple rice bran }=2039 \pm 82^{\mathrm{c}} \\
70 \% \text { ethanol extract of red rice bran }=2266 \pm 16^{\mathrm{c}}\end{array}$ & - & - \\
\hline $\begin{array}{l}\mathrm{a}[73] . \\
\mathrm{b}[70] . \\
{ }^{\mathrm{c}}[63] \\
{ }^{[}[74]\end{array}$ & & & \\
\hline
\end{tabular}

Compared with other cereal brans, such as corn, wheat, and oat, the lipid proportion present in brewers' rice has a unique ratio of vitamin $\mathrm{E}$ isoforms $(\alpha-, \gamma$-, and $\delta$-tocopherols and tocotrienols) and $\gamma$-oryzanol [72].

Since phenolic compounds are demonstrated to confer beneficial health benefits, this may partially explain a better nutritional value of rice by-products. Biological activities in the cereal grains were strongly correlated to their polyphenols content [85], which is known to exhibit potent antioxidant activities [86-88]. Majority of the antioxidants commonly present in fruits, vegetables, and cereals (wheat, rice, and oat) are polyphenolic compounds [89-92]. Li et al. [89] reported that most of the phenolic acids present in the whole grains are ferulic acid, p-coumaric acid, vanillic acid, caffeic acid, and syringic acid. Others have also reached a similar finding, in which the rice grains were rich in ferulic acid and $\mathrm{p}$ coumaric acid $[93,94]$. In view of the total phenolic content in various genotypes of rice by-products, rice brans have 2-11fold higher content than rice husk, 4-15-fold higher content than brown rice, and 7-59-fold greater content than polished rice [95].

\section{Anticancer Activities of Rice By-Products}

4.1. In Vitro Cancer Chemopreventive Study. Colorectal cancer chemoprevention activity highlighted the role of 
bioactive constituents like rice bran phytic acid [96], tricin, and flavonoids [97]. Relative proportions of bioactive components in rice bran have been shown to inhibit the growth of colorectal cancer cells; however, they are different among other rice varieties [71]. Kong et al. [98] reported that rice bran phenolic compound cycloartenyl ferulate inhibited the proliferation of human colorectal adenocarcinoma (SW480) cell line. Chen et al. [63] used different cancer cell lines to study the cell-inhibiting activity in response to red rice bran extract and demonstrated that red bran exhibited strong inhibitory effects against leukemia, cervical, and stomach cancers. Forster et al. [71] also reported that total phenolics and $\gamma$-tocotrienol from rice bran exhibited significantly reduced colorectal cancer cell proliferation $(p<0.05)$. Another rice by-product, momilactone $\mathrm{B}$, an allelochemical of rice hull, has antiproliferative activity against human leukemic T-cells via activation of caspase and mitochondria pathways [99]. In addition to the effects observed in leukemic cancer, methanol extract of rice husk also inhibited the growth of colon cancer cells with inhibition concentration $\left(\mathrm{IC}_{50}\right)$ values of $0.5 \mu \mathrm{g} / \mathrm{mL}$ [100].

Study on the effect of brewers' rice on colorectal cancer (HT-29) cell line was conducted by Tan et al. [72, 74]. They reported that water extract of brewers' rice (WBR) inhibited the proliferation of HT-29 cell line and the effect was suggested to be linked to the bioactive compounds present in WBR. The extract, however, was not cytotoxic against normal cell lines [72]. This finding was consistent with the data obtained by Ryan et al. [101], Fan et al. [102], and Kong et al. [98], who reported that the rice bran components were not cytotoxic against normal cell lines. Summary of in vitro studies on antiproliferative effect of rice by-products is shown in Table 6.

4.2. In Vivo Cancer Chemopreventive Study. Rice germ or the constituents present in the rice bran or germ have been identified to have chemopreventive effects against carcinogenesis in the colon [125], liver [126], stomach [127], esophagus [128], and bladder [129] of rodents. Kong et al. [98] observed that rice bran cycloartenyl ferulate significantly induced suppression of human colorectal adenocarcinoma (SW480) of xenograft in nude mice after 21 days and triggered both death receptor and mitochondrial apoptosis pathways. Similarly, Kim et al. [122] used pathogen-free female BALB/c mice to evaluate the effect of rice bran $\gamma$-oryzanol on colon tumor growth and found that rice bran $\gamma$-oryzanol could inhibit colon tumor and reduce expression of vascular endothelial growth factor (VEGF), cyclooxygenase-2 (COX-2), and 5lipoxygenase (5-LOX). In another study, Choi et al. [123] further demonstrated that feeding a diet containing $10 \%$ $(\mathrm{w} / \mathrm{w})$ black and brown rice brans reduced VEGF, COX-2, and 5-LOX expression in mouse colon carcinoma cells- (CT-26-) treated mice. Increased COX-2 expression, an inflammatory gene, is positively associated with the inflammatory response strength [130]. Reduction of COX-2 suggests that black and brown rice brans could attenuate the inflammatory response in cancer through reduction of oxidative stress. Interestingly, feeding with rice bran not only reduced the number of aberrant crypt foci (ACF) [120] but also improved lipid profile as described by Ausman et al. [131] suggesting the numerous functional potentials of rice bran. Additionally, Kawabata et al. [113] reported that feeding azoxymethane (AOM) $(15 \mathrm{mg} / \mathrm{kg}$ body weight once weekly for 3 weeks) with rice germ for 5 weeks significantly suppressed colon adenocarcinoma $(p<0.01)$ in rats. Mori et al. [114] also observed that the ACF/colon in the rats induced with $\mathrm{AOM}$ and fed with rice germ $(2.5 \%$ in diet) were significantly reduced compared to those of the group with AOM only $(p<0.005)$. In addition to the effects observed on rice bran and rice germ, using male F344 rats model that received carcinogen 1,2-methylhydrazine (DMH) subcutaneously once weekly for 6 weeks at a dosage of $180 \mathrm{mg} / \mathrm{kg}$ body weight, Kim et al. demonstrated that the methanolic extract of rice husk could reduce colon preneoplastic ACF formation by $35 \%$ after 40 weeks $(p<0.01$ ) [100]. In view of the apoptotic-inducing efficacy observed in HT-29 cell line on water extract of brewers' rice (WBR), findings from an animal study mirror some of those from preclinical data obtained from an in vitro study. Tan et al. [55] reported that feeding AOM-induced colon cancer rats $(15 \mathrm{mg} / \mathrm{kg}$ body weight) with a diet containing $40 \%$ brewers' rice reduced significantly colon tumor multiplicity after 20 weeks of treatment $(p<0.05)$. The suppressive effects seen in the highest concentration of brewers' rice treatment could be explained by its higher concentrations of active compounds that may confer better functional properties. However, it is not yet clearly understood which bioactive constituents are responsible for the functional benefits of brewers' rice, but it is more likely that several of the phytonutrients contribute towards these observed effects. Among the studies described to date, the improvements in these indices could be attributed to higher levels of $\gamma$-oryzanol, phytic acid, vitamin E, and antioxidants [72]. So, it is important to encourage long-term clinical studies to verify these findings by providing a better alternative to curb the rising incidence and prevalence of colon cancer.

Several studies as reported by Henderson et al. [33] also demonstrated that rice by-products have chemopreventive potential not only in the colon but also in the breast, lung, mouth, bladder, liver, esophagus, and melanoma/skin in vivo. Wang et al. [119] observed that defatted rice bran sulfated polysaccharide (SRBPS2a) suppressed the implanted EMT-6 breast tumor cells growth in BALB/c mice. In another study, Yasukawa et al. [112] demonstrated that feeding ICR mice with rice bran cycloartenol ferulate is possible to suppress tumor promotion in 2-stage skin carcinoma. Furthermore, defatted rice germ has also been reported to reduce the incidence of tongue carcinomas and preneoplastic lesions in Fisher 344 rats [114] (Table 7).

The beneficial effects of bioactive components observed in rice by-products, as reported above, have been postulated by the concept of food synergy [132]. If so, the synergistic/additive effects of bioactive compounds in rice byproducts could in the long term be beneficial in the management of cancer via multiple mechanisms perhaps even better than some drugs as suggested by Ricciardiello et al. [133] who suggested that whole food or whole food extract can have high importance in combating carcinogenesis. These 
TABLE 6: Anticancer effect of rice by-products in vitro.

\begin{tabular}{|c|c|c|c|}
\hline Author(s) & Year & Components & Findings \\
\hline $\begin{array}{l}\text { Hudson et } \\
\text { al. [62] }\end{array}$ & 2000 & $\begin{array}{l}\text { Rice bran phenolic extracts (tricin, ferulic acid, } \\
\text { caffeic acid, and methoxycinnamic acid) }\end{array}$ & $\begin{array}{l}\text { Reduced the number of viable SW } 480 \text { cells and } \\
\text { inhibited the colony-forming ability. }\end{array}$ \\
\hline $\begin{array}{l}\text { Luo et al. } \\
{[103]}\end{array}$ & 2005 & $\begin{array}{l}\text { Gamma-oryzanol (cycloartenyl trans-ferulate and } \\
24 \text {-methylenecycloartanol trans-ferulate) from } \\
\text { rice bran }\end{array}$ & Moderate cytotoxicity effect against MCF-7 cells. \\
\hline $\begin{array}{l}\text { Kim et al. } \\
{[100]}\end{array}$ & 2007 & Methanol extract of rice husk & $\begin{array}{l}\text { Highly cytotoxic against colon cancer cells, with } \\
\text { IC }_{50} \text { value of } 0.5 \mu \mathrm{g} / \mathrm{mL} \text {. }\end{array}$ \\
\hline $\begin{array}{l}\text { Gollapudi } \\
\text { and } \\
\text { Ghoneum } \\
{[104]}\end{array}$ & 2008 & $\begin{array}{l}\text { MGN-3/biobran, modified arabinoxylan from } \\
\text { rice bran }\end{array}$ & $\begin{array}{l}\text { Treatment with MGN-3 increased susceptibility of } \\
\text { human breast cancer cells to daunorubicin } \\
\text { (5.5-fold for MCF-7 and } 2.5 \text {-fold for HCC70 cells) } \\
\text { compared with that of human breast cancer cells } \\
\text { treated with daunorubicin alone. }\end{array}$ \\
\hline $\begin{array}{l}\text { Joung et al. } \\
{[105]}\end{array}$ & 2008 & Momilactone B, an allelochemical of rice husk & $\begin{array}{l}\text { Suppressed hypoxia-induced increases of cyclin } \\
\text { D1 in human breast cancer cells. }\end{array}$ \\
\hline $\begin{array}{l}\text { Kannan et } \\
\text { al. [106] }\end{array}$ & 2008 & $\begin{array}{l}\text { Peptide hydrolysates derived from heat-stabilized } \\
\text { defatted rice bran }\end{array}$ & $\begin{array}{l}\text { Suppressed the proliferation of Caco- } 2 \text { and } \\
\text { HepG2 cancer cells. }\end{array}$ \\
\hline $\begin{array}{l}\text { Lee et al. } \\
{[99]}\end{array}$ & 2008 & Momilactone B, an allelochemical of rice husks & $\begin{array}{l}\text { Inhibited the proliferation of human leukemic } \\
\text { T-cells (Jurkat). }\end{array}$ \\
\hline $\begin{array}{l}\text { Punyatong } \\
\text { et al. [107] }\end{array}$ & 2008 & $\mathrm{PA}$ and $\mathrm{C} 3 \mathrm{G}$ in purple glutinous rice bran & $\begin{array}{l}\text { Dose-dependent cytotoxic effect on X63, a } \\
\text { mouse-plasma cancer cell line of myeloma cells. }\end{array}$ \\
\hline $\begin{array}{l}\text { Kannan et } \\
\text { al. [108] }\end{array}$ & 2009 & Peptide hydrolysates derived from rice bran & $\begin{array}{l}\text { Cytotoxicity effect of }<5 \mathrm{kDa} \text { peptide fraction } \\
\text { separated from rice bran protein hydrolysate } \\
\text { against HCT-116. }\end{array}$ \\
\hline $\begin{array}{l}\text { Kong et al. } \\
{[98]}\end{array}$ & 2009 & Rice bran cycloartenyl ferulate & $\begin{array}{l}\text { Induced apoptosis in SW } 480 \text { and SW620 cells } \\
\text { through activation of caspase- } 3 \text { and caspase- } 8 \text {. }\end{array}$ \\
\hline $\begin{array}{l}\text { Kannan et } \\
\text { al. [109] }\end{array}$ & 2010 & Peptides derived from defatted rice bran & Inhibited Caco-2 and HCT-116 cells growth. \\
\hline $\begin{array}{l}\text { Nurul- } \\
\text { Husna et } \\
\text { al. [110] }\end{array}$ & 2010 & Rice bran phytic acid & Suppressed the proliferation of HT-29 cells. \\
\hline $\begin{array}{l}\text { Chen et al. } \\
{[63]}\end{array}$ & 2012 & Red rice bran & $\begin{array}{l}\text { Exhibited strong inhibition on leukemia, cervical, } \\
\text { and stomach cancer cells. }\end{array}$ \\
\hline $\begin{array}{l}\text { Forster et } \\
\text { al. [71] }\end{array}$ & 2013 & Rice bran (variety Jasmine 85) & $\begin{array}{l}\text { Exhibited a strong inhibitory effect against Caco-2 } \\
\text { and HT-29 cells. }\end{array}$ \\
\hline $\begin{array}{l}\text { Takashima } \\
\text { et al. [111] }\end{array}$ & 2013 & Water and ethanol extracts of rice bran & Markedly inhibited the growth of LS174T cells. \\
\hline $\begin{array}{l}\text { Tan et al. } \\
{[72]}\end{array}$ & 2013 & WBR and methanol extract of brewers' rice & Inhibited the proliferation of HT-29 cell line. \\
\hline
\end{tabular}

C3G: cyanidin 3-glucoside; Caco-2: colon cancer cells; HCC70: human breast cancer cells; HCT-116: human colon cancer; HepG2: liver cancer; HT-29: human colorectal cancer; $\mathrm{IC}_{50}$ : inhibition concentration for 50\%; LS174T: human colon cancer; MCF-7: human breast adenocarcinoma; PA: proanthocyanidin; SW480: human colon cancer; SW620: human colon cancer; WBR: water extract of brewers' rice.

observations also supported the finding by Tsuda et al. [134] who demonstrated a synergistic and/or additive protective effect of several bioactive compounds.

\section{Mechanisms of Action of Rice By-Products as Anticancer Agent}

5.1. Apoptosis Induction and Inhibition of Cancer Cellular Proliferation. Apoptosis or programmed cell death plays a crucial role in the tissues maintenance, organ homeostasis, and genetically controlled cell death to balance cell proliferation [135]. Apoptosis is a normal and continuous process in healthy subjects accompanied with complex physiological processes, which controls some of the vital cellular processes like cell turnover, maintaining homeostasis of cell population, development of the immune system, hormone-dependent atrophy, embryonic development, and chemical-induced cell death [136]. Inappropriate regulation of apoptotic cell death mechanism has been identified in numerous human diseases. Thus, aberrant apoptosis contributes to cancer progression. Apoptosis can be stimulated via internal and external stimuli. An internal stimulus can be a p53 tumor suppressor gene, while external stimulus is external plasma membrane associated receptors [137].

The ability to modulate cell death is identified as a potential therapeutic agent for cancer. Numerous bioactive 
TABLE 7: Anticancer effect of rice by-products in vivo.

\begin{tabular}{lcl}
\hline Author(s) & Year & Components \\
\hline $\begin{array}{l}\text { Yasukawa } \\
\text { et al. [112] }\end{array}$ & 1998 & Rice bran cycloartenol ferulate \\
\hline $\begin{array}{l}\text { Kawabata } \\
\text { et al. [113] }\end{array}$ & 1999 & Rice germ \\
\hline
\end{tabular}

Mori et al. [114]
Rice germ

1999
Findings

Suppressed tumor promotion in 2-stage skin carcinoma in ICR mice.

Suppressed ACF formation and reduced incidence of colonic adenocarcinoma.

Reduced the numbers of $\mathrm{ACF} / \mathrm{colon}, \mathrm{ACF} / \mathrm{cm}^{2}$, and aberrant crypts/colon in the group treated with $\mathrm{AOM}+\mathrm{GABA}$-enriched defatted rice germ (2.5\% in diet) and the group treated with $\mathrm{AOM}+$ rice germ $(2.5 \%$ in diet) compared with that of the group treated with AOM alone. Inhibited AOM-induced large bowel neoplasms incidences in Fisher 344 rats.

Ferulic acid and defatted rice germ

\begin{tabular}{|c|c|c|c|}
\hline $\begin{array}{l}\text { Mori et al. } \\
{[115]}\end{array}$ & 2000 & Rice germ and GABA-enriched defatted rice germ & $\begin{array}{l}\text { Suppressed AOM-induced ACF and colon } \\
\text { carcinogenesis in rats. }\end{array}$ \\
\hline $\begin{array}{l}\text { Cai et al. } \\
{[97]}\end{array}$ & 2005 & Tricin from rice bran & $\begin{array}{l}\text { Reduced the number of intestinal adenomas via } \\
\text { the suppression of COX activity and inhibited } \\
\mathrm{PGE}_{2} \text { production. }\end{array}$ \\
\hline $\begin{array}{l}\text { Kim et al. } \\
{[100]}\end{array}$ & 2007 & Methanol extract of rice husk & $\begin{array}{l}\text { Decreased colonic preneoplastic ACF formation } \\
\text { by } 35 \% \text {. }\end{array}$ \\
\hline $\begin{array}{l}\text { Verschoyle } \\
\text { et al. [8] }\end{array}$ & 2007 & $30 \%$ rice bran & $\begin{array}{l}\text { Reduced numbers of intestinal adenomas in } \\
\text { APC }^{\mathrm{Min}} \text { mice. }\end{array}$ \\
\hline $\begin{array}{l}\text { Kawasaki } \\
\text { et al. [116] }\end{array}$ & 2008 & Rice bran hemicellulose & $\begin{array}{l}\text { Inhibited the total number of colon tumors and } \\
\text { tumor incidence in Fisher } 344 \text { rats. }\end{array}$ \\
\hline $\begin{array}{l}\text { Boateng et } \\
\text { al. [117] }\end{array}$ & 2009 & Rice bran & $\begin{array}{l}\text { Dietary administration of } 5 \% \text { and } 10 \% \text { of rice bran } \\
\text { significantly }(p<0.05) \text { reduced the } \\
\text { AOM-induced colon tumors incidence in male } \\
\text { Fisher } 344 \text { rats after } 44 \text { weeks of feeding. }\end{array}$ \\
\hline $\begin{array}{l}\text { Panala et } \\
\text { al. [118] }\end{array}$ & 2009 & Rice bran oil & Inhibited incidence of ACF in Fisher 344 rats. \\
\hline $\begin{array}{l}\text { Wang et al. } \\
\text { [119] }\end{array}$ & 2009 & $\begin{array}{l}\text { Defatted rice bran sulfated polysaccharide } \\
\text { (SRBPS2a) }\end{array}$ & $\begin{array}{l}\text { Suppressed implanted EMT-6 breast tumor cells } \\
\text { growth in BALB/c mice. }\end{array}$ \\
\hline $\begin{array}{l}\text { Norazalina } \\
\text { et al. [96] }\end{array}$ & 2010 & Rice bran phytic acid & $\begin{array}{l}\text { Reduced the number of ACF in the distal, middle, } \\
\text { and proximal colon. }\end{array}$ \\
\hline $\begin{array}{l}\text { Li et al. } \\
{[120]}\end{array}$ & 2011 & Rice bran & $\begin{array}{l}\text { Suppressed the number of ACF and expression of } \\
\text { COX-2 in the middle colon. }\end{array}$ \\
\hline $\begin{array}{l}\text { Shih et al. } \\
{[121]}\end{array}$ & 2011 & Rice bran oil & $\begin{array}{l}\text { Suppressed colon tumor formation, } \\
\text { mucin-depleted foci, and ACF especially } \\
\text { sialomucin-producing ACF in } \\
\text { 1,2-dimethylhydrazine/dextran sodium sulphate } \\
\text { induced colitis-associated colon cancer after } 13 \\
\text { weeks of feeding. }\end{array}$ \\
\hline $\begin{array}{l}\text { Kim et al. } \\
{[122]}\end{array}$ & 2012 & Rice bran $\gamma$-oryzanol & Inhibited colon tumor growth in mice. \\
\hline $\begin{array}{l}\text { Choi et al. } \\
{[123]}\end{array}$ & 2013 & $10 \%(\mathrm{w} / \mathrm{w})$ black and brown rice brans & Inhibited the colon transplanted tumors in mice. \\
\hline $\begin{array}{l}\text { Shafie et } \\
\text { al. [124] }\end{array}$ & 2013 & Rice bran phytic acid & $\begin{array}{l}\text { Markedly reduced } \beta \text {-catenin and COX- } 2 \\
\text { expression in colon tumors. }\end{array}$ \\
\hline $\begin{array}{l}\text { Tan et al. } \\
{[55]}\end{array}$ & 2014 & Brewers' rice & Markedly reduced colon tumor in rats. \\
\hline
\end{tabular}

ACF: aberrant crypt foci; AOM: azoxymethane; APC: adenomatous polyposis coli; COX: cyclooxygenase; COX-2: cyclooxygenase-2; GABA: gammaaminobutyric acid; $\mathrm{PGE}_{2}$ : prostaglandin $\mathrm{E}_{2}$.
Reduced the incidence of tongue carcinomas and preneoplastic lesions in Fisher 344 rats.

Suppressed AOM-induced ACF and colon carcinogenesis in rats. $\mathrm{PGE}_{2}$ production. by $35 \%$. $\mathrm{APC}^{\mathrm{Min}}$ mice. tumor incidence in Fisher 344 rats.

Dietary administration of $5 \%$ and $10 \%$ of rice bran AOM-induced colon tumors incidence in male growth in $\mathrm{BALB} / \mathrm{c}$ mice. and proximal colon. COX-2 in the middle colon.

Suppressed colon tumor formation, sialomucin-producing ACF in 1,2-dimethylhydrazine/dextran sodium sulphate induced colitis-associated colon cancer after 13 
compounds present in rice bran like ferulic acid [95], $\gamma$ oryzanol, phytic acid [138], p-coumaric acid [139], pectin [140], tricin, and tocotrienol-tocopherols are believed to be responsible for inducing apoptosis [101]. As shown by Serafim et al. [141], caffeic and ferulic acid derivatives play a crucial role in the increase of tumor suppressor protein p53 expression and enhance the mitochondrial depolarization and chromatin condensation. In addition to the effects observed on caffeic and ferulic acid, vitamin E, particularly tocotrienols, has also been shown to induce cell cycle arrest [142], activate p53 and caspase activity [143, 144], inhibit adhesion molecules [145], suppress nuclear factor-kappa B $(\mathrm{NF}-\kappa \mathrm{B})$ [146], and downregulate c-Myc and telomerase [147]. Kannappan et al. [148] further demonstrated that $\gamma$ tocotrienol not only has the ability to downregulate the Bcl-2 and $\mathrm{Bcl}-\mathrm{xL}$ antiapoptotic proteins expression but also induces SHP-1 expression, which directly suppresses the activation of STAT3, as STAT3 pathway correlated well with cancer progression. Furthermore, $\gamma$-tocotrienol-induced apoptosis was also demonstrated in Hep3B cells via caspase-3, caspase8 , and caspase- 9 activities with the participation of Bax and Bid [149]. Findings by Ahn et al. [146] further showed that $\gamma$-tocotrienol suppressed the NF- $\kappa \mathrm{B}$ activation pathway via inhibition of receptor-interacting protein (RIP) and TAK1 and thus suppressed the antiapoptotic gene and contributed to apoptosis. Another vitamin $\mathrm{E}$ isomer, $\delta$-tocotrienol, also induced apoptosis in human breast cancer cells through involvement of transforming growth factor- $\beta$, Fas, and c-Jun $\mathrm{N}$-terminal kinase (JNK) signaling pathways [150].

In addition to the bioactive compounds mentioned above, $\beta$-sitosterol has also been reported to have a beneficial effect against colorectal, stomach, and breast cancers [151, 152]. The possible mechanism is by increasing the damage of the cancer cell membrane, activation of caspase-3 activity [152], and increasing the production of cellular ceramide, which is related to the cell cycle arrest [151]. Study on the effect of water extract of brewers' rice (WBR) treatment also resulted in the induction of apoptosis by significant activation of caspase- 3 and caspase- 8 activities [153]. Momilactone B, an allelochemical extracted from rice husks, was also shown to induce apoptosis in human lymphoma (Jurkat) cells through caspase and mitochondria pathways [99].

In addition to the prevention of the initiation stage of cancer via the induction of apoptosis, it is also vital for cancer chemopreventive agents to suppress the proliferation of malignant cells. Phytic acid is generally known as an antinutrient compound due to its propensity to form a complex with minerals and subsequently contributed to deficiencies in animal/human. It was also revealed from several in vitro and in vivo studies to have potential in suppressing abnormal cell proliferation $[124,154]$.

The efficacy of these bioactive compounds as anticancer agents, however, depends on the bioavailability and the dosage [155]. For example, gastrointestinal esterases in the large and small intestines of humans and rats can release diferulic acid from bran fiber, which may promote its bioavailability [156]. In addition, ferulic acid also remains in the bloodstream longer and hence may confer more protection than other known antioxidants. On the other hand, even though phytic acid has been shown to inhibit the proliferation of cancer cells, the absorption in the small intestines of humans is low and relies on plasma concentration $[157,158]$. However, several studies suggested that the bioavailability of phytic acid depends on the source of food that it comes from.

5.2. Regulation of Wnt/ $\beta$-Catenin Signaling Pathway. Deregulation of Wnt/ $\beta$-catenin signaling has been demonstrated to be associated with cancer especially with colorectal cancer [159-164]. Cyclin D1 is a well-known cell cycle protein targeted by $\beta$-catenin [165] that is frequently overexpressed in colon tumor tissues [166]. c-Myc is another vital protein in the regulation of cell growth by $\beta$-catenin and the Wnt pathway [167]. Leardkamolkarn et al. [168] reported that methanol extract of Thai rice, Riceberry bran, diminished the amount of cyclin D1 in colonic carcinoma (Caco-2) cell line. In this study, reduction of cyclin D1 observed in colon carcinoma cells, however, was attributed to vitamin $\mathrm{E}$ or tocotrienol content [169]. Similarly, Sun et al. [170] and Gysin et al. [169] reported that vitamin $\mathrm{E}$ or tocotrienol reduced the expression of cyclin D1 in gastric adenocarcinoma and prostate carcinoma. In addition to vitamin $\mathrm{E}$, rice bran phytic acid has also been reported to have a similar effect in diminishing the expression of $\beta$-catenin, which could potentially reduce colon carcinogenesis [171]. Inhibition of colon carcinogenesis via modulation of Wnt/ $\beta$-catenin signaling pathway was also shown in brewers' rice and its water extract (WBR). As indicated in Figure 2, WBR upregulated mRNA levels of casein kinase 1 (CK1) and adenomatous polyposis coli (APC), a destruction complex involved in the degradation of $\beta$ catenin, and inhibited the low-density lipoprotein receptorrelated protein 6 (LRP6), which is a crucial coreceptor in Wnt signaling, and glycogen synthase kinase $3 \beta(G S K 3 \beta)$ mRNA levels [153]. The fact that WBR downregulates GSK3 $\beta$ and produces better colon tumor inhibition suggests that other mechanisms are involved in WBR's anti-colon cancer properties and are likely modulated by NF- $\kappa \mathrm{B}[172,173]$. Additionally, brewers' rice also reduced $\beta$-catenin, cyclin D1, and c-Myc expression, as illustrated in Figure 3 [153]. Preclinical findings from in vitro and in vivo studies on mechanisms involved in anti-colon cancer effects suggest that rice by-products could modulate Wnt pathway in colon cancer.

5.3. Modulation of Inflammation Pathway. Numerous bioactive components present in rice by-products have been demonstrated to facilitate cancer chemoprevention through the enhancement of immune response. These cancer chemopreventive immune responses serve either via blocking viral infections related to virus-induced tumors or by specific suppression of tumor cells [174]. The early stages of an inflammatory response are vital in the protection against infection and injury; however, an uncontrolled or chronic inflammatory environment is favorable towards cancer development [33]. Chronic infection and inflammation stimulate the inflammatory-associated genes such as NF- $\kappa \mathrm{B}$ [175] and inducible nitric oxide synthase (iNOS) expression [176]. As reported by Henderson et al. [177], the whole dietary rice 


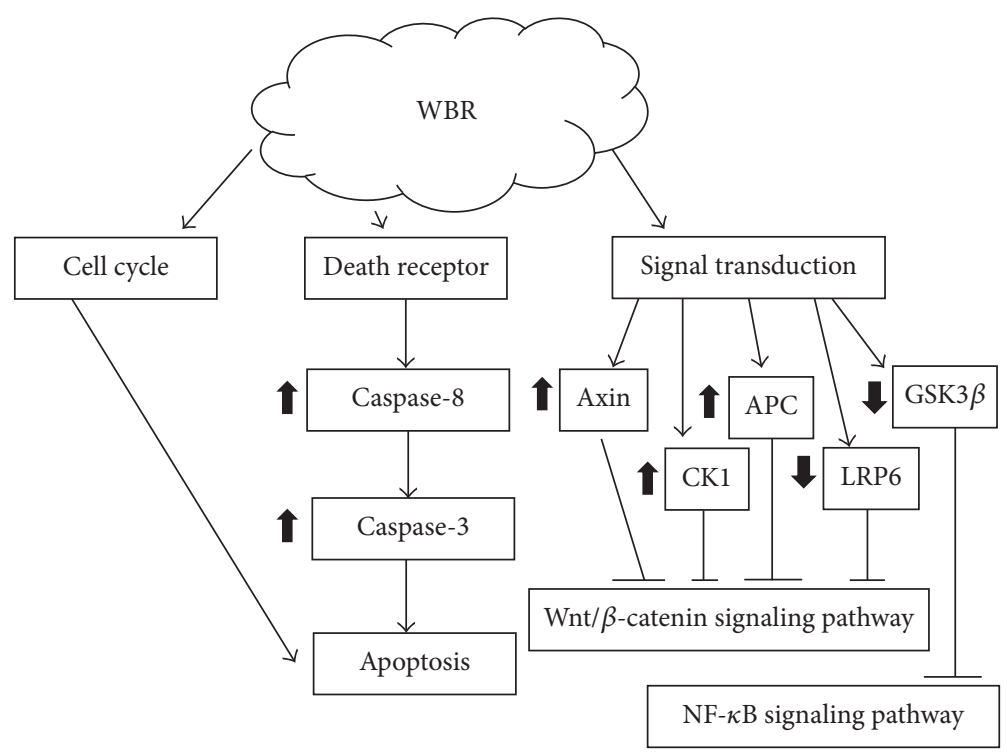

Upregulated

Downregulated

FIGURE 2: Summary of mechanisms involved in colorectal cancer (HT-29) cells of water extract of brewers' rice (WBR). APC: adenomatous polyposis coli; CK1: casein kinase 1; GSK3 $\beta$ : glycogen synthase kinase $3 \beta$; NF- $\kappa$ B: nuclear factor-kappa B; LRP6: low-density lipoprotein receptor-related protein 6; WBR: water extract of brewers' rice.

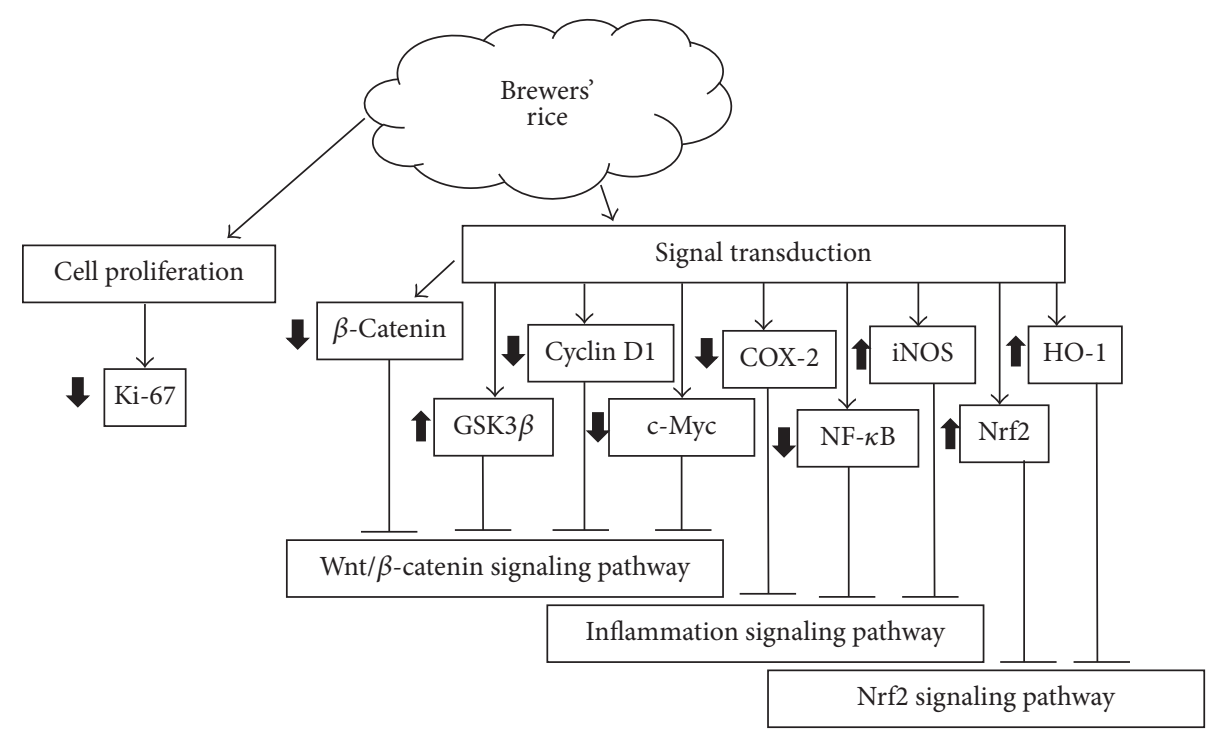

1 Upregulated

$\downarrow$ Downregulated

FIGURE 3: Summary of mechanisms involved in colon tumorigenesis of brewers' rice. COX-2: cyclooxygenase-2; GSK3 $\beta$ : glycogen synthase kinase $3 \beta$; HO-1: heme oxygenase-1; iNOS: inducible nitric oxide synthase; NF- $\kappa$ B: nuclear factor-kappa B; Nrf2: NF-E2-related factor 2.

bran modulates the mucosal immune response by increasing the numbers of mesenteric lymph nodes and lamina propria dendritic cells [177]. They also revealed that ferulic acid from rice bran has potential to be a promising cancer chemopreventive agent to inhibit the lipopolysaccharide-
(LPS-) induced iNOS and COX-2 protein expression as well as suppress the release of tumor necrosis factor- $\alpha$ (TNF- $\alpha)$. This phenomenon was associated with the inhibition of I$\kappa \mathrm{B}$ phosphorylation and subsequently suppression of $\mathrm{NF}-\kappa \mathrm{B}$ signaling [178]. 
An earlier study by Morel et al. [179] reported the ability of $\alpha$-tocopherol to promote cytokine production and monocyte recruitment, which are required in the adaptive immunity development. Boxer [180] and Sakurai et al. [181] also showed that $\alpha$-tocopherol and ferulic acid promote the respiratory burst and interferon- $\gamma$ production in macrophages, respectively. A previous study by Sierra et al. [182] also reported the ability of rice bran oil to regulate the immune response by promoting the proliferation of B-cell and inducing interleukin-2 (IL-2) and TNF- $\alpha$ production. In addition, rice bran extract MGN-3 has been demonstrated to promote dendritic cell maturation [183] and enhance cytokine production and natural killer (NK) cell activity [184].

Feeding mice with diet supplemented with black rice bran extract prior to 12-O-tetradecanoylphorbol-13-acetate (TPA) administration was also shown to inhibit inflammation (edema) caused by TPA by a marked reduction in proinflammatory cytokines TNF- $\alpha$, interleukin- $1 \beta$ (IL-1 $\beta$ ), interleukin-6 (IL-6), and eicosanoids leukotriene B4 (LTB4) [185]. Gamma-oryzanol primarily consists of esters of transferulic acid (trans-hydroxycinnamic acid) and phytosterols (sterols and triterpenic alcohols). Cycloartenol, $\beta$-sitosterol, 24-methylenecycloartenol, and campesterol are present predominantly in $\gamma$-oryzanol $[186,187]$. Anti-inflammatory effects of $\gamma$-oryzanol and cycloartenyl trans-ferulate markedly suppressed the inflammatory response in mice-induced colitis [188]. Accordingly, Islam et al. [189] demonstrated that rice bran phytosteryl ferulates modulated anti-inflammatory reactions via downregulation of inflammatory transcription factor, NF- $\kappa \mathrm{B}$, which may lead to the reduction of inflammatory enzymes like COX-2 and iNOS and proinflammatory cytokines such as IL-1 $\beta$, IL-6, and TNF- $\alpha$. Rice bran phytosteryl ferulates further enhanced blood adiponectin levels through indirect stimulation of peroxisomal proliferatoractivated receptor- $\gamma(\operatorname{PPAR} \gamma)$ via suppression of NF- $\kappa \mathrm{B}$. Collectively, rice bran $\gamma$-oryzanol inhibited tumor growth via stimulation of cytolytic activity in splenic (NK) cells, partial restoration of nitric oxide production, and phagocytosis in peritoneal macrophages, subsequently resulting in the liberation of proinflammatory cytokines TNF- $\alpha$, IL-1 $\beta$, and IL- 6 from macrophages.

MGN-3/biobran, arabinoxylan rice bran, was shown to have antitumor activity, through modulation of immune systems such as NK cells [190-192], TNF- $\alpha$ [184, 193], and macrophages [194]. The investigators found that MGN-3 suppresses tumor in solid Ehrlich carcinoma- (SEC-) bearing mice via induction of apoptosis through its immunomodulatory effects [184]. Additionally, isovitexin from rice husk has also been demonstrated to inhibit release of COX-2 expression and reduced LPS-stimulated prostaglandin $\mathrm{E}_{2}$ [195]. In addition to the effects observed in rice bran and rice husk in the inflammation pathway, brewers' rice has also been demonstrated to have a similar effect against COX-2 activity. It was shown to reduce COX-2 and NF$\kappa \mathrm{B}$ levels. Findings from animal study also revealed that brewers' rice upregulated iNOS [196]. This is in agreement with an earlier finding that overexpression of iNOS attenuates the proliferation and metastasis of human renal cell carcinomas and murine fibrosarcoma [197]. In this regard, natural components present in the brewers' rice such as polyphenolic compounds, including ferulic acid, gallic acid, p-coumaric acid, syringic acid, vanillic acid [74], and vitamin E isomers, $\gamma$-oryzanol [72], and $\gamma$-aminobutyric acid (GABA) [198] have the potential to inhibit the proinflammatory immune signaling and subsequently reduce the colon cancer development.

5.4. Protection against Free Radicals and Modulation of Antioxidant Pathway. One of the effective mechanisms for cancer prevention is to inhibit initiation stage through suppression of the DNA damage caused by reactive oxygen species (ROS) or other carcinogens [199]. Oxidative stress can cause significant cellular damage and irreversible mutations; thus, a substantial amount of antioxidant may protect cells from free radical damage.

Study by Tan et al. [196] showed that dietary administration of brewers' rice helped to protect against oxidative stress in AOM-induced rat colon carcinogenesis by improved antioxidant capacity like superoxide dismutase (SOD), malondialdehyde (MDA), and nitric oxide (NO). They also observed that brewers' rice upregulated NF-E2related factor $2(\mathrm{Nrf} 2)$ signaling pathway via modulation of Nrf2 and heme oxygenase-1 (HO-1) transcriptional activities (Figure 3). Earlier study by Tan et al. [55] also reported that brewers' rice consists of phenolic antioxidants, phytic acid, vitamin E, oryzanol, and $\gamma$-aminobutyric acid (GABA) which were shown by many previous studies to have a good antioxidant capacity. Ferulic acid, for example, is a well-documented phenolic compound that can be found in high amount in rice by-products, demonstrated to be an effective superoxide anion radical scavenger and lipid peroxidation inhibitor [155]. In another study, ferulic acid has been reported to protect against hydrogen peroxide-induced cellular damage via elevation of cellular levels of HO-1 and heat shock protein-70 [200]. Overall, this suggests that the protective effect of rice by-product on oxidative stress may be mediated partly via the synergistic/additive effects of these bioactive constituents.

Besides bioactive compounds stated above, MGN-3, an arabinoxylan extracted from rice bran, has also been reported to induce oncostatic activity against murine solid Ehrlich carcinoma via modulation of lipid peroxidation and enhanced the endogenous antioxidant scavenging activity such as SOD, glutathione peroxidase (GPx), catalase (CAT), and glutathione-S-transferase (GST) [201].

\section{Summary and Future Prospects}

This review has provided substantial evidence both in vitro and in vivo that consumption of rice by-products may provide the optimal chemoprevention due to antioxidant phytonutrients. Further clinical studies of rice by-products and their unique bioactive compounds hold great promise in future use as a dietary cancer chemopreventive agent.

In conclusion, rice by-products as a cancer chemopreventive dietary agent represent a unique approach to evaluate 
effective whole food compared to the individual phytochemical. Our review showed a promising result from both in vitro and in vivo studies, which warrants clinical studies designed to gain a better understanding of the relationship between rice bran/rice husk/rice germ/brewers' rice and cancers. The global availability and affordability of rice by-products provide a better public health opportunity in both developed and developing countries. Taken together, this review could pave the way for the potential use of rice by-products as a functional food in the prevention and treatment of cancers. The potential implication of the dietary intake of rice byproducts in place of conventional treatment modalities could be significant and is warranted to be evaluated further in long-term clinical studies.

\section{Competing Interests}

The authors declare that there are no competing interests regarding the publication of this paper.

\section{References}

[1] K. S. vel Szic, A. Palagani, B. Hassannia et al., "Phytochemicals and cancer chemoprevention: epigenetics friends or foe?" in Phytochemicals- Bioactivities and Impact on Health, InTech, Rijeka, Croatia, 2011.

[2] P. Anand, A. B. Kunnumakara, C. Sundaram et al., "Cancer is a preventable disease that requires major lifestyle changes," Pharmaceutical Research, vol. 25, no. 9, pp. 2097-2116, 2008.

[3] Y. Tantamango-Bartley, K. Jaceldo-Siegl, J. Fan, and G. Fraser, "Vegetarian diets and the incidence of cancer in a low-risk population," Cancer Epidemiology Biomarkers and Prevention, vol. 22, no. 2, pp. 286-294, 2013.

[4] W. C. Willett, "Balancing life-style and genomics research for disease prevention," Science, vol. 296, no. 5568, pp. 695-698, 2002.

[5] M. B. Sporn, "Approaches to prevention of epithelial cancer during the preneoplastic period," Cancer Research, vol. 36, no. 7, part 2, pp. 2699-2702, 1976.

[6] W.-L. Lin, W.-H. Liang, Y.-J. Lee, S.-K. Chuang, and T.-H. Tseng, "Antitumor progression potential of caffeic acid phenethyl ester involving p75 ${ }^{N T R}$ in C6 glioma cells," Chemico-Biological Interactions, vol. 188, no. 3, pp. 607-615, 2010.

[7] B. Fisher, J. P. Costantino, D. L. Wickerham et al., "Tamoxifen for prevention of breast cancer: report of the National Surgical Adjuvant Breast and Bowel Project P-1 study," Journal of the National Cancer Institute, vol. 90, no. 18, pp. 1371-1388, 1998.

[8] R. D. Verschoyle, P. Greaves, H. Cai, R. E. Edwards, W. P. Steward, and A. J. Gescher, "Evaluation of the cancer chemopreventive efficacy of rice bran in genetic mouse models of breast, prostate and intestinal carcinogenesis," British Journal of Cancer, vol. 96, no. 2, pp. 248-254, 2007.

[9] V. G. Vogel, J. P. Costantino, D. L. Wickerham et al., "Effects of tamoxifen vs raloxifene on the risk of developing invasive breast cancer and other disease outcomes: the NSABP Study of Tamoxifen and Raloxifene (STAR) P-2 trial," The Journal of the American Medical Association, vol. 295, no. 23, pp. 2727-2741, 2006.

[10] Food and Agriculture Organization of the United Nations (FAOSTAT), 2014, http://faostat3.fao.org/download/Q/QC/E.
[11] A. R. M. R. Amin, O. Kucuk, F. R. Khuri, and D. M. Shin, "Perspectives for cancer prevention with natural compounds," Journal of Clinical Oncology, vol. 27, no. 16, pp. 2712-2725, 2009.

[12] T. M. De Kok, S. G. Van Breda, and M. M. Manson, "Mechanisms of combined action of different chemopreventive dietary compounds: a review," European Journal of Nutrition, vol. 47, no. 2, pp. 51-59, 2008.

[13] S. D. Stan, S. Kar, G. D. Stoner, and S. V. Singh, "Bioactive food components and cancer risk reduction," Journal of Cellular Biochemistry, vol. 104, no. 1, pp. 339-356, 2008.

[14] T. Kuno, T. Tsukamoto, A. Hara, and T. Tanaka, "Cancer chemoprevention through the induction of apoptosis by natural compounds," Journal of Biophysical Chemistry, vol. 3, no. 2, pp. 156-173, 2012.

[15] J.-A. Shin, J. S. Kim, I.-S. Hong, and S.-D. Cho, "Bak is a key molecule in apoptosis induced by methanol extracts of Codonopsis lanceolata and Tricholoma matsutake in HSC-2 human oral cancer cells," Oncology Letters, vol. 4, no. 6, pp. 1379-1383, 2012.

[16] Q. J. Wu, Y. Yang, E. Vogtmann et al., "Cruciferous vegetables intake and the risk of colorectal cancer: a meta-analysis of observational studies," Annals of Oncology, vol. 24, no. 4, pp. 1079-1087, 2013.

[17] S. R. McWhinney, R. M. Goldberg, and H. L. McLeod, "Platinum neurotoxicity pharmacogenetics," Molecular Cancer Therapeutics, vol. 8, no. 1, pp. 10-16, 2009.

[18] M. Minami, S. Matsumoto, and H. Horiuchi, "Cardiovascular side-effects of modern cancer therapy," Circulation Journal, vol. 74, no. 9, pp. 1779-1786, 2010.

[19] J. W. Jang, C. S. Kay, C. R. You et al., "Simultaneous multitarget irradiation using helical tomotherapy for advanced hepatocellular carcinoma with multiple extrahepatic metastases," International Journal of Radiation Oncology, Biology, Physics, vol. 74, no. 2, pp. 412-418, 2009.

[20] A. Kane and I. Yang, "Interferon-gamma in brain tumor immunotherapy," Neurosurgery Clinics of North America, vol. 21, no. 1, pp. 77-86, 2010.

[21] Y. Refaely and D. Weissberg, "Surgical management of tracheal tumors," The Annals of Thoracic Surgery, vol. 64, no. 5, pp. 14291432, 1997.

[22] S. Hemalswarya and M. Doble, "Potential synergism of natural products in the treatment of cancer," Phytotherapy Research, vol. 20, no. 4, pp. 239-249, 2006.

[23] C. D. Lao and D. E. Brenner, "Strategies for prevention of colorectal cancer: pharmaceutical and nutritional interventions," Current Treatment Options in Oncology, vol. 5, no. 5, pp. 417426, 2004.

[24] P. Pingali, "Westernization of Asian diets and the transformation of food systems: implications for research and policy," Food Policy, vol. 32, no. 3, pp. 281-298, 2007.

[25] H. C. J. Godfray, J. R. Beddington, I. R. Crute et al., "Food security: the challenge of feeding 9 billion people," Science, vol. 327, no. 5967, pp. 812-818, 2010.

[26] D. Tilman, C. Balzer, J. Hill, and B. L. Befort, "Global food demand and the sustainable intensification of agriculture," Proceedings of the National Academy of Sciences of the United States of America, vol. 108, no. 50, pp. 20260-20264, 2011.

[27] J. A. Foley, N. Ramankutty, K. A. Brauman et al., "Solutions for a cultivated planet," Nature, vol. 478, no. 7369, pp. 337-342, 2011.

[28] FAO, Global Agriculture Towards 2050, FAO, Rome, Italy, 2009. 
[29] OECD/FAO, OECD-FAO Agricultural Outlook 2012-2021, OECD Publishing and FAO, 2012.

[30] FAO WFP and IFAD, The State of Food Insecurity in the World 2012. Economic Growth is Necessary but not Sufficient to Accelerate Reduction of Hunger and Malnutrition, FAO, Rome, Italy, 2012.

[31] M. C. S. Wopereis, T. Dofoer, P. Indinoba, S. Diack, and M. Dugue, "Curriculum for participatory learning and action research (PLAR) for integrated rice management (IRM) in inland valleys of sub-saharan Africa," Technical Manual, African Rice Center (WARDA), 2009.

[32] D. K. Ray, N. D. Mueller, P. C. West, and J. A. Foley, "Yield trends are insufficient to double global crop production by 2050," PLoS ONE, vol. 8, no. 6, Article ID e66428, 2013.

[33] A. J. Henderson, C. A. Ollila, A. Kumar et al., "Chemopreventive properties of dietary rice bran: current status and future prospects," Advances in Nutrition, vol. 3, no. 5, pp. 643-653, 2012.

[34] E. T. Champagne, D. F. Wood, B. O. Juliano, and D. B. Bechtel, "The rice grain and its gross composition," in Rice Chemistry and Technology, pp. 77-107, American Association of Cereal Chemists Press, Minneapolis, Minn, USA, 2004.

[35] E. P. Ryan, "Bioactive food components and health properties of rice bran," Journal of the American Veterinary Medical Association, vol. 238, no. 5, pp. 593-600, 2011.

[36] M. W. Zhang, R. F. Zhang, F. X. Zhang, and R. H. Liu, "Phenolic profiles and antioxidant activity of black rice bran of different commercially available varieties," Journal of Agricultural and Food Chemistry, vol. 58, no. 13, pp. 7580-7587, 2010.

[37] N. M. Esa, T. B. Ling, and L. S. Peng, "By-products of rice processing: an overview of health benefits and applications," Journal of Rice Research, vol. 1, no. 1, p. 107, 2013.

[38] D. J. Farrell and K. Hutton, "Rice and rice milling by-products," in Nontraditional Feed Sources for Use in Swine Production, P. A. Thacker and R. N. Kirkwood, Eds., chapter 24, Butterworths Publishers, Stoneham, Mass, USA, 1990.

[39] NGFA (National Grain \& Feed Association), Rice Fractions, NGFA, Grafton, Wis, USA, 2003, http://www.Ingredients101.com/ricefrac.htm.

[40] NRC (National Research Council), United States-Canadian Tables of Feed Composition, National Academy Press, Washington, DC, USA, 1982.

[41] NRC, Nutrient Requirements of Poultry (Ninth Revised Edition), National Academy Press, Washington, DC, USA, 1994.

[42] NRC, Nutrient Requirements of Swine, National Academy Press, Washington, DC, USA, 10th edition, 1998, http://books.nap.edu/catalog/2114.html.

[43] AgrEvo, "Safety, compositional and nutritional aspects of LibertyLink Rice Transformation events LLRICE06 and LLRICE62," U.S. FDA/CFSANBNF, 63, 1999.

[44] D. Ffoulkes, "Rice as a livestock feed," Agnote (Northern Territory of Australia), vol. 273, no. 22, pp. 1-3, 1998.

[45] FAO, Animal Feed Resources Information System. Oryza sativa, 2003, http://www.fao.org/livestock/agap/frg/AFRIS/default.htm.

[46] D. Herd, Composition of Alternative Feeds-Dry Basis, Texas A\&M University, College Station, Tex, USA, 2003.

[47] B. O. Juliano and D. B. Bechtel, "The rice grain and its gross composition," in Rice: Chemistry and Technology, B. O. Juliano, Ed., pp. 17-35, American Association of Cereal Chemists, St. Paul, Minn, USA, 1985.
[48] E. R. Miller, D. E. Ullrey, and A. J. Lewis, Swine Nutrition, Butterworth-Heinemann, Boston, Mass, USA, 1991.

[49] NRC, Nutrient Requirements of Beef Cattle (Update 2000), National Academy Press, Washington, DC, USA, 2000.

[50] NRC, Nutrient Requirements of Dairy Cattle (Seventh Revised Edition), National Academy Press, Washington, DC, USA, 2001, http://books.nap.edu/catalog/9825.html.

[51] D. J. Drake, G. Nader, and L. Forero, Feeding Rice Straw to Cattle, Publication 8079, University of California's Division of Agriculture and Natural Resources, Davis, Calif, USA, 2002, http://anrcatalog.ucdavis.edu.

[52] J. G. Fadel and D. J. MacKill, "Characterization of rice straw," - 94. U. of California, Davis, CA, 2002, http://www.syix.com/rrb/94rpt/RiceStraw.htm.

[53] M. Wanapat, K. Sommart, and K. Saardrak, "Cottonseed meal supplementation of dairy cattle fed rice straw," Livestock Research for Rural Development, vol. 8, no. 3, 1996.

[54] A. M. Nour, "Rice straw and rice hulls in feeding ruminants in Egypt," Department Animal Production, Alexandria U., Alexandria, Egypt, 2003, http://www.ssdairy.org/AdditionalRes/x5494e/x5494e07.htm.

[55] B. L. Tan, N. M. Esa, H. S. Rahman, H. Hamzah, and R. Karim, "Brewers' rice induces apoptosis in azoxymethane-induced colon carcinogenesis in rats via suppression of cell proliferation and the Wnt signaling pathway," BMC Complementary and Alternative Medicine, vol. 14, article 304, 2014.

[56] AOAC (Association of Official Analytical Chemists), Official Methods of Analysis of AOAC International, AOAC, Gaithersburg, Md, USA, 17th edition, 2002.

[57] Organization for Economic Co-Operation and Development, "Consensus document on compositional considerations for new varieties of rice (Oryza sativa): key food and feed nutrients and anti-nutrients," in Annual Report 2004, Organization for Economic Co-Operation and Development, Paris, France, 2004.

[58] N. Worasuwannarak, T. Sonobe, and W. Tanthapanichakoon, "Pyrolysis behaviors of rice straw, rice husk, and corncob by TG-MS technique," Journal of Analytical and Applied Pyrolysis, vol. 78, no. 2, pp. 265-271, 2007.

[59] L. Chatenoud, A. Tavani, C. La Vecchia et al., "Whole grain food intake and cancer risk," International Journal of Cancer, vol. 77, no. 1, pp. 24-28, 1998.

[60] G.-F. Deng, X.-R. Xu, Y. Zhang, D. Li, R.-Y. Gan, and H.-B. $\mathrm{Li}$, "Phenolic compounds and bioactivities of pigmented rice," Critical Reviews in Food Science and Nutrition, vol. 53, no. 3, pp. 296-306, 2013.

[61] K. A. Steinmetz and J. D. Potter, "Vegetables, fruit, and cancer. I. Epidemiology," Cancer Causes \& Control, vol. 2, no. 5, pp. 325$357,1991$.

[62] E. A. Hudson, P. A. Dinh, T. Kokubun, M. S. J. Simmonds, and A. Gescher, "Characterization of potentially chemopreventive phenols in extracts of brown rice that inhibit the growth of human breast and colon cancer cells," Cancer Epidemiology, Biomarkers and Prevention, vol. 9, no. 11, pp. 1163-1170, 2000.

[63] M.-H. Chen, S. H. Choi, N. Kozukue, H.-J. Kim, and M. Friedman, "Growth-inhibitory effects of pigmented rice bran extracts and three red bran fractions against human cancer cells: relationships with composition and antioxidative activities," Journal of Agricultural and Food Chemistry, vol. 60, no. 36, pp. 9151-9161, 2012. 
[64] K. A. Moldenhauer, E. T. Champagne, D. R. McCaskill, and H. Guraya, "Functional products from rice," in Functional Foods, G. Mazza, Ed., pp. 71-89, Technomic Publishing, Basel, Switzerland, 2003.

[65] R. Renuka Devi and C. Arumughan, "Antiradical efficacy of phytochemical extracts from defatted rice bran," Food and Chemical Toxicology, vol. 45, no. 10, pp. 2014-2021, 2007.

[66] C. Canan, F. Delaroza, R. Casagrande, M. M. Baracat, M. Shimokomaki, and E. I. Ida, "Antioxidant capacity of phytic acid purified from rice bran," Acta Scientiarum, vol. 34, no. 4, pp. 457-463, 2012.

[67] C. Chotimarkorn, S. Benjakul, and N. Silalai, "Antioxidant components and properties of five long-grained rice bran extracts from commercial available cultivars in Thailand," Food Chemistry, vol. 111, no. 3, pp. 636-641, 2008.

[68] P. Imsanguan, A. Roaysubtawee, R. Borirak, S. Pongamphai, S. Douglas, and P. L. Douglas, "Extraction of $\alpha$-tocopherol and $\gamma$ oryzanol from rice bran," LWT-Food Science and Technology, vol. 41, no. 8, pp. 1417-1424, 2008.

[69] P. Lai, K. Y. Li, S. Lu, and H. H. Chen, "Phytochemicals and antioxidant properties of solvent extracts from Japonica rice bran," Food Chemistry, vol. 117, no. 3, pp. 538-544, 2009.

[70] S. Butsat and S. Siriamornpun, "Antioxidant capacities and phenolic compounds of the husk, bran and endosperm of Thai rice," Food Chemistry, vol. 119, no. 2, pp. 606-613, 2010.

[71] G. M. Forster, K. Raina, A. Kumar et al., "Rice varietal differences in bioactive bran components for inhibition of colorectal cancer cell growth," Food Chemistry, vol. 141, no. 2, pp. 15451552, 2013.

[72] B. L. Tan, M. E. Norhaizan, H. J. Suhaniza, C. C. Lai, S. Norazalina, and K. Roselina, "Antioxidant properties and antiproliferative effect of brewers' rice extract (temukut) on selected cancer cell lines," International Food Research Journal, vol. 20, no. 5, pp. 2117-2124, 2013.

[73] S. Butsat, N. Weerapreeyakul, and S. Siriamornpun, "Changes in phenolic acids and antioxidant activity in Thai rice husk at five growth stages during grain development," Journal of Agricultural and Food Chemistry, vol. 57, no. 11, pp. 4566-4571, 2009.

[74] B. L. Tan, M. E. Norhaizan, S. K. Yeap, and K. Roselina, "Water extract of brewers' rice induces antiproliferation of human colorectal cancer (HT-29) cell lines via the induction of apoptosis," European Review for Medical and Pharmacological Sciences, vol. 19, no. 6, pp. 1022-1029, 2015.

[75] U. Kalapathy, A. Proctor, and J. Shultz, "Silicate thermal insulation material from rice hull ash," Industrial and Engineering Chemistry Research, vol. 42, no. 1, pp. 46-49, 2003.

[76] A. Moure, J. M. Cruz, D. Franco et al., "Natural antioxidants from residual sources," Food Chemistry, vol. 72, no. 2, pp. 145171, 2001.

[77] K. Mochidzuki, A. Sakoda, M. Suzuki, J. Izumi, and N. Tomonaga, "Structural behavior of rice husk silica in pressurized hotwater treatment processes," Industrial and Engineering Chemistry Research, vol. 40, no. 24, pp. 5705-5709, 2001.

[78] G. Garrote, E. Falqué, H. Domínguez, and J. C. Parajó, "Autohydrolysis of agricultural residues: study of reaction byproducts," Bioresource Technology, vol. 98, no. 10, pp. 1951-1957, 2007.

[79] A. Saija, A. Tomaino, R. Lo Cascio et al., "Ferulic and caffeic acids as potential protective agents against photooxidative skin damage," Journal of the Science of Food and Agriculture, vol. 79, no. 3, pp. 476-480, 1999.
[80] K.-I. Jeon, E. Park, H.-R. Park, Y.-J. Jeon, S.-H. Cha, and S.C. Lee, "Antioxidant activity of far-infrared radiated rice hull extracts on reactive oxygen species scavenging and oxidative DNA damage in human lymphocytes," Journal of Medicinal Food, vol. 9, no. 1, pp. 42-48, 2006.

[81] S. Yu, Z. T. Nehus, T. M. Badger, and N. Fang, "Quantification of vitamin $\mathrm{E}$ and $\gamma$-oryzanol components in rice germ and bran," Journal of Agricultural and Food Chemistry, vol. 55, no. 18, pp. 7308-7313, 2007.

[82] N. N. A. M. Nordin, R. Karim, H. M. Ghazali, N. M. Adzahan, and M. T. Sultan, "Effects of various stabilization techniques on the nutritional quality and antioxidant potential of brewer's rice," Journal of Engineering Science and Technology, vol. 9, no. 3, pp. 347-363, 2014.

[83] J. Glatthar, J. J. Heinisch, and T. Senn, "The use of unmalted triticale in brewing and its effect on wort and beer quality," Journal of the American Society of Brewing Chemists, vol. 61, no. 4, pp. 182-190, 2003.

[84] Association of American feed Control Officials, "Brewers rice," 2011, http://www.aafco.org/.

[85] J. M. Awika, L. Dykes, L. Gu, L. W. Rooney, and R. L. Prior, "Processing of sorghum (Sorghum bicolor) and sorghum products alters procyanidin oligomer and polymer distribution and content," Journal of Agricultural and Food Chemistry, vol. 51, no. 18, pp. 5516-5521, 2003.

[86] H. Zieliński and H. Kozłowska, "Antioxidant activity and total phenolics in selected cereal grains and their different morphological fractions," Journal of Agricultural and Food Chemistry, vol. 48, no. 6, pp. 2008-2016, 2000.

[87] K. E. Heim, A. R. Tagliaferro, and D. J. Bobilya, "Flavonoid antioxidants: chemistry, metabolism and structure-activity relationships," The Journal of Nutritional Biochemistry, vol. 13, no. 10, pp. 572-584, 2002.

[88] V. Rastija and M. Medić-Šarić, "QSAR study of antioxidant activity of wine polyphenols," European Journal of Medicinal Chemistry, vol. 44, no. 1, pp. 400-408, 2009.

[89] L. Li, P. R. Shewry, and J. L. Ward, "Phenolic acids in wheat varieties in the HEALTHGRAIN diversity screen," Journal of Agricultural and Food Chemistry, vol. 56, no. 21, pp. 9732-9739, 2008.

[90] N. Andarwulan, R. Batari, D. A. Sandrasari, B. Bolling, and H. Wijaya, "Flavonoid content and antioxidant activity of vegetables from Indonesia," Food Chemistry, vol. 121, no. 4, pp. 1231-1235, 2010.

[91] B. N. Dar and S. Sharma, "Total phenolic content of cereal brans using conventional and microwave assisted extraction," American Journal of Food Technology, vol. 6, no. 12, pp. 10451053, 2011.

[92] P. Vanzani, M. Rossetto, V. de Marco, L. E. Sacchetti, M. G. Paoletti, and A. Rigo, "Wild mediterranean plants as traditional food: a valuable source of antioxidants," Journal of Food Science, vol. 76, no. 1, pp. C46-C51, 2011.

[93] S. Tian, K. Nakamura, and H. Kayahara, "Analysis of phenolic compounds in white rice, brown rice, and germinated brown rice," Journal of Agricultural and Food Chemistry, vol. 52, no. 15, pp. 4808-4813, 2004.

[94] Z. Zhou, K. Robards, S. Helliwell, and C. Blanchard, "The distribution of phenolic acids in rice," Food Chemistry, vol. 87, no. 3, pp. 401-406, 2004.

[95] S.-H. Huang and L.-T. Ng, "Quantification of polyphenolic content and bioactive constituents of some commercial rice 
varieties in Taiwan," Journal of Food Composition and Analysis, vol. 26, no. 1-2, pp. 122-127, 2012.

[96] S. Norazalina, M. E. Norhaizan, I. Hairuszah, and M. S. Norashareena, "Anticarcinogenic efficacy of phytic acid extracted from rice bran on azoxymethane-induced colon carcinogenesis in rats," Experimental and Toxicologic Pathology, vol. 62 , no. 3, pp. 259-268, 2010.

[97] H. Cai, M. Al-Fayez, R. G. Tunstall et al., "The rice bran constituent tricin potently inhibits cyclooxygenase enzymes and interferes with intestinal carcinogenesis in $A p c^{M i n}$ mice," Molecular Cancer Therapeutics, vol. 4, no. 9, pp. 1287-1292, 2005.

[98] C. K. L. Kong, W. S. Lam, L. C. M. Chiu, V. E. C. Ooi, S. S. M. Sun, and Y.-S. Wong, "A rice bran polyphenol, cycloartenyl ferulate, elicits apoptosis in human colorectal adenocarcinoma SW480 and sensitizes metastatic SW620 cells to TRAIL-induced apoptosis," Biochemical Pharmacology, vol. 77, no. 9, pp. 1487-1496, 2009.

[99] S. C. Lee, I.-M. Chung, Y. J. Jin et al., "Momilactone B, an allelochemical of rice hulls, induces apoptosis on human lymphoma cells (Jurkat) in a micromolar concentration," Nutrition and Cancer, vol. 60, no. 4, pp. 542-551, 2008.

[100] S.-J. Kim, H.-R. Park, E. Park, and S.-C. Lee, "Cytotoxic and antitumor activity of momilactone B from rice hulls," Journal of Agricultural and Food Chemistry, vol. 55, no. 5, pp. 1702-1706, 2007.

[101] E. P. Ryan, A. L. Heuberger, T. L. Weir, B. Barnett, C. D. Broeckling, and J. E. Prenni, "Rice bran fermented with Saccharomyces boulardii generates novel metabolite profiles with bioactivity," Journal of Agricultural and Food Chemistry, vol. 59, no. 5, pp. 1862-1870, 2011.

[102] H. Fan, T. Morioka, and E. Ito, "Induction of apoptosis and growth inhibition of cultured human endometrial adenocarcinoma cells (Sawano) by an antitumor lipoprotein fraction of rice bran," Gynecologic Oncology, vol. 76, no. 2, pp. 170-175, 2000.

[103] H.-F. Luo, Q. L. Li, S. G. Yu, T. M. Badger, and N. B. Fang, "Cytotoxic hydroxylated triterpene alcohol ferulates from rice bran," Journal of Natural Products, vol. 68, no. 1, pp. 94-97, 2005.

[104] S. Gollapudi and M. Ghoneum, "MGN-3/Biobran, modified arabinoxylan from rice bran, sensitizes human breast cancer cells to chemotherapeutic agent, daunorubicin," Cancer Detection and Prevention, vol. 32, no. 1, pp. 1-6, 2008.

[105] Y.-H. Joung, E.-J. Lim, M.-S. Kim et al., "Enhancement of hypoxia-induced apoptosis of human breast cancer cells via STAT5b by momilactone B," International Journal of Oncology, vol. 33, no. 3, pp. 477-484, 2008.

[106] A. Kannan, N. Hettiarachchy, M. G. Johnson, and R. Nannapaneni, "Human colon and liver cancer cell proliferation inhibition by peptide hydrolysates derived from heat-stabilized defatted rice bran," Journal of Agricultural and Food Chemistry, vol. 56, no. 24, pp. 11643-11647, 2008.

[107] M. Punyatong, P. Pongpiachan, P. Pongpiachan, D. Karladee, and S. Mankhetkorn, "Cytotoxicity of crude proanthocyanidin extract from purple glutinous rice bran (Oryza sativa L.) (Kum Doi Saket) compared with cyanidin 3-glucoside on X63 myeloma cancer cell lines," Kasetsart Journal - Natural Science, vol. 42, no. 4, pp. 676-681, 2008.

[108] A. Kannan, N. Hettiarachchy, and S. Narayan, "Colon and breast anti-cancer effects of peptide hydrolysates derived from rice bran," The Open Bioactive Compounds Journal, vol. 2, no. 1, pp. 17-20, 2009.

[109] A. Kannan, N. S. Hettiarachchy, J. O. Lay, and R. Liyanage, "Human cancer cell proliferation inhibition by a pentapeptide isolated and characterized from rice bran," Peptides, vol. 31, no. 9, pp. 1629-1634, 2010.

[110] S. Nurul-Husna, M. E. Norhaizan, I. Hairuszah, M. A. Abdah, S. Norazalina, and I. Norsharina, "Rice bran phytic acid $\left(\mathrm{IP}_{6}\right)$ induces growth inhibition, cell cycle arrest and apoptosis on human colorectal adenocarcinoma cells," Journal of Medicinal Plants Research, vol. 4, no. 21, pp. 2283-2289, 2010.

[111] A. Takashima, M. Ohtomo, T. Kikuchi, J. Iwashita, T. Abe, and K. Hata, "Differentiation- and apoptosis-inducing activities of rice bran extracts in a human colon cancer cell line," Journal of Food Science and Technology, vol. 50, no. 3, pp. 595-599, 2013.

[112] K. Yasukawa, T. Akihisa, Y. Kimura, T. Tamura, and M. Takido, "Inhibitory effect of cycloartenol ferulate, a component of rice bran, on tumor promotion in two-stage carcinogenesis in mouse skin," Biological and Pharmaceutical Bulletin, vol. 21, no. 10, pp. 1072-1076, 1998.

[113] K. Kawabata, T. Tanaka, T. Murakami et al., "Dietary prevention of azoxymethane-induced colon carcinogenesis with rice-germ in F344 rats," Carcinogenesis, vol. 20, no. 11, pp. 2109-2115, 1999.

[114] H. Mori, K. Kawabata, N. Yoshimi et al., "Chemopreventive effects of ferulic acid on oral and rice germ on large bowel carcinogenesis," Anticancer Research, vol. 19, no. 5, pp. 37753778, 1999.

[115] H. Mori, K. Kawabata, K. Matsunaga et al., "Chemopreventive effects of coffee bean and rice constituents on colorectal carcinogenesis," BioFactors, vol. 12, no. 1-4, pp. 101-105, 2000.

[116] B. T. Kawasaki, E. M. Hurt, T. Mistree, and W. L. Farrar, "Targeting cancer stem cells with phytochemicals," Molecular Interventions, vol. 8, no. 4, pp. 174-184, 2008.

[117] J. Boateng, M. Verghcse, V. Panala, L. T. Walker, and L. Shackelford, "Protective effects of rice bran on chemically induced colon tumorigenesis may be due to synergistic/additive properties of bioactive components," International Journal of Cancer Research, vol. 5, no. 4, pp. 153-166, 2009.

[118] V. Panala, M. Verghese, J. Boateng, R. Field, L. Shackelford, and L. T. Walker, "A comparison of rice bran, corn oil and soybean oil against azoxymethane induced colon cancer in a Fisher 344 rat model," International Journal of Cancer Research, vol. 5, no. 1, pp. 25-35, 2009.

[119] L. Wang, H. Huang, Y. Wei, X. Li, and Z. Chen, "Characterization and anti-tumor activities of sulfated polysaccharide SRBPS2a obtained from defatted rice bran," International Journal of Biological Macromolecules, vol. 45, no. 4, pp. 427-431, 2009.

[120] S.-C. Li, T.-C. Chou, and C.-K. Shih, "Effects of brown rice, rice bran, and polished rice on colon carcinogenesis in rats," Food Research International, vol. 44, no. 1, pp. 209-216, 2011.

[121] C.-K. Shih, C.-J. Ho, S.-C. Li, S.-H. Yang, W.-C. Hou, and H.-H. Cheng, "Preventive effects of rice bran oil on 1,2dimethylhydrazine/dextran sodium sulphate-induced colon carcinogenesis in rats," Food Chemistry, vol. 126, no. 2, pp. 562$567,2011$.

[122] S. P. Kim, M. Y. Kang, S. H. Nam, and M. Friedman, "Dietary rice bran component $\gamma$-oryzanol inhibits tumor growth in tumor-bearing mice," Molecular Nutrition and Food Research, vol. 56, no. 6, pp. 935-944, 2012.

[123] S. P. Choi, S. P. Kim, S. H. Nam, and M. Friedman, "Antitumor effects of dietary black and brown rice brans in tumor-bearing mice: relationship to composition," Molecular Nutrition and Food Research, vol. 57, no. 3, pp. 390-400, 2013.

[124] N. H. Shafie, N. Mohd Esa, H. Ithnin, A. Md Akim, N. Saad, and A. K. Pandurangan, "Preventive inositol hexaphosphate 
extracted from rice bran inhibits colorectal cancer through involvement of Wnt $/ \beta$-catenin and COX-2 pathways," BioMed Research International, vol. 2013, Article ID 681027, 10 pages, 2013.

[125] M. Katyama, N. Yoshimi, Y. Yamada et al., "Preventive effect of fermented brown rice and rice bran against colon carcinogenesis in male F344 rats," Oncology Reports, vol. 9, no. 4, pp. 817$822,2002$.

[126] M. Katayama, S. Sugie, N. Yoshimi et al., "Preventive effect of fermented brown rice and rice bran on diethylnitrosoamine and phenobarbital-induced hepatocarcinogenesis in male F344 rats," Oncology Reports, vol. 10, no. 4, pp. 875-880, 2003.

[127] H. Tomita, T. Kuno, Y. Yamada et al., "Preventive effect of fermented brown rice and rice bran on N. methyl-N/nitro.N-nitrosoguanidine-induced gastric carcinogenesis in rats," Oncology Reports, vol. 19, no. 1, pp. 11-15, 2008.

[128] T. Kuno, Y. Hirose, K. Hata et al., "Preventive effect of fermented brown rice and rice bran on N-nitrosomethylbenzylamineinduced esophageal tumorigenesis in rats," International Journal of Oncology, vol. 25, no. 6, pp. 1809-1815, 2004.

[129] T. Kuno, Y. Hirose, Y. Yamada et al., "Chemoprevention of mouse urinary bladder carcinogenesis by fermented brown rice and rice bran," Oncology Reports, vol. 15, no. 3, pp. 533-538, 2006.

[130] Y. Niu, B. Gao, M. Slavin et al., "Phytochemical compositions, and antioxidant and anti-inflammatory properties of twentytwo red rice samples grown in Zhejiang," LWT_Food Science and Technology, vol. 54, no. 2, pp. 521-527, 2013.

[131] L. M. Ausman, N. Rong, and R. J. Nicolosi, "Hypocholesterolemic effect of physically refined rice bran oil: studies of cholesterol metabolism and early atherosclerosis in hypercholesterolemic hamsters," The Journal of Nutritional Biochemistry, vol. 16, no. 9, pp. 521-529, 2005.

[132] D. R. Jacobs Jr. and L. C. Tapsell, "Food, not nutrients, is the fundamental unit in nutrition," Nutrition Reviews, vol. 65, no. 10, pp. 439-450, 2007.

[133] L. Ricciardiello, F. Bazzoli, and V. Fogliano, "Phytochemicals and colorectal cancer prevention-myth or reality?" Nature Reviews Gastroenterology and Hepatology, vol. 8, no. 10, pp. 592596, 2011.

[134] H. Tsuda, Y. Ohshima, H. Nomoto et al., "Cancer prevention by natural compounds," Drug Metabolism and Pharmacokinetics, vol. 19, no. 4, pp. 245-263, 2004.

[135] N. Khan, F. Afaq, and H. Mukhtar, "Apoptosis by dietary factors: the suicide solution for delaying cancer growth," Carcinogenesis, vol. 28, no. 2, pp. 233-239, 2007.

[136] H. Cheung, X. Liu, and O. M. Rennert, "Apoptosis: reprogramming and the fate of mature cells," ISRN Cell Biology, vol. 2012, Article ID 685852, 8 pages, 2012.

[137] X. Jiang and X. Wang, "Cytochrome C-mediated apoptosis," Annual Review of Biochemistry, vol. 73, pp. 87-106, 2004.

[138] M. Verghese, D. R. Rao, C. B. Chawan, L. T. Walker, and L. Shackelford, "Anticarcinogenic effect of phytic acid $\left(\mathrm{IP}_{6}\right)$ : apoptosis as a possible mechanism of action," LWT-Food Science and Technology, vol. 39, no. 10, pp. 1093-1098, 2006.

[139] B. Janicke, G. Önning, and S. M. Oredsson, "Differential effects of ferulic acid and p-coumaric acid on $S$ phase distribution and length of S phase in the human colonic cell line Caco-2," Journal of Agricultural and Food Chemistry, vol. 53, no. 17, pp. 66586665, 2005.
[140] C. L. Jackson, T. M. Dreaden, L. K. Theobald et al., "Pectin induces apoptosis in human prostate cancer cells: correlation of apoptotic function with pectin structure," Glycobiology, vol. 17, no. 8, pp. 805-819, 2007.

[141] T. L. Serafim, F. S. Carvalho, M. P. M. Marques et al., "Lipophilic caffeic and ferulic acid derivatives presenting cytotoxicity against human breast cancer cells," Chemical Research in Toxicology, vol. 24, no. 5, pp. 763-774, 2011.

[142] J. K. Srivastava and S. Gupta, "Tocotrienol-rich fraction of palm oil induces cell cycle arrest and apoptosis selectively in human prostate cancer cells," Biochemical and Biophysical Research Communications, vol. 346, no. 2, pp. 447-453, 2006.

[143] M. K. Agarwal, M. L. Agarwal, M. Athar, and S. Gupta, "Tocotrienol-rich fraction of palm oil activates p53, modulates $\mathrm{Bax} / \mathrm{Bcl} 2$ ratio and induces apoptosis independent of cell cycle association," Cell Cycle, vol. 3, no. 2, pp. 205-211, 2004.

[144] S. Shah and P. W. Sylvester, "Tocotrienol-induced caspase-8 activation is unrelated to death receptor apoptotic signaling in neoplastic mammary epithelial cells," Experimental Biology and Medicine, vol. 229, no. 8, pp. 745-755, 2004.

[145] A. Theriault, J.-T. Chao, and A. Gapor, "Tocotrienol is the most effective vitamin $\mathrm{E}$ for reducing endothelial expression of adhesion molecules and adhesion to monocytes," Atherosclerosis, vol. 160, no. 1, pp. 21-30, 2002.

[146] K. S. Ahn, G. Sethi, K. Krishnan, and B. B. Aggarwal, " $\gamma$-Tocotrienol inhibits nuclear factor- $\kappa \mathrm{B}$ signaling pathway through inhibition of receptor-interacting protein and TAK1 leading to suppression of antiapoptotic gene products and potentiation of apoptosis," Journal of Biological Chemistry, vol. 282, no. 1, pp. 809-820, 2007.

[147] T. Eitsuka, K. Nakagawa, and T. Miyazawa, "Down-regulation of telomerase activity in DLD-1 human colorectal adenocarcinoma cells by tocotrienol," Biochemical and Biophysical Research Communications, vol. 348, no. 1, pp. 170-175, 2006.

[148] R. Kannappan, V. R. Yadav, and B. B. Aggarwal, " $\gamma$-tocotrienol but not $\gamma$-tocopherol blocks STAT3 cell signaling pathway through induction of protein-tyrosine phosphatase SHP-1 and sensitizes tumor cells to chemotherapeutic agents," The Journal of Biological Chemistry, vol. 285, no. 43, pp. 33520-33528, 2010.

[149] M. Sakai, M. Okabe, H. Tachibana, and K. Yamada, "Apoptosis induction by $\gamma$-tocotrienol in human hepatoma Hep3B cells," The Journal of Nutritional Biochemistry, vol. 17, no. 10, pp. 672676, 2006.

[150] M.-C. Shun, W. Yu, A. Gapor et al., "Pro-apoptotic mechanisms of action of a novel vitamin E analog ( $\alpha$-TEA) and a naturally occurring form of vitamin $\mathrm{E}$ ( $\delta$-Tocotrienol) in MDA-MB-435 human breast cancer cells," Nutrition and Cancer, vol. 48, no. 1 , pp. 95-105, 2004.

[151] A. B. Awad, S. L. Barta, C. S. Fink, and P. G. Bradford, “ $\beta$ Sitosterol enhances tamoxifen effectiveness on breast cancer cells by affecting ceramide metabolism," Molecular Nutrition and Food Research, vol. 52, no. 4, pp. 419-426, 2008.

[152] Y. Zhao, S. K. C. Chang, G. Qu, T. Li, and H. Cui, “ $\beta$ Sitosterol inhibits cell growth and induces apoptosis in SGC7901 human stomach cancer cells," Journal of Agricultural and Food Chemistry, vol. 57, no. 12, pp. 5211-5218, 2009.

[153] B. L. Tan, M. E. Norhaizan, K. Huynh et al., "Water extract of brewers' rice induces apoptosis in human colorectal cancer cells via activation of caspase- 3 and caspase- 8 and downregulates the $\mathrm{Wnt} / \beta$-catenin downstream signaling pathway in brewers' ricetreated rats with azoxymethane-induced colon carcinogenesis," 
BMC Complementary and Alternative Medicine, vol. 15, article 205, 2015.

[154] S. Norazalina, M. E. Norhaizan, I. Hairuszah, A. R. Sabariah, S. N. Husna, and I. Norsharina, "Antiproliferation and apoptosis induction of phytic acid in hepatocellular carcinoma (HEPG2) cell lines," African Journal of Biotechnology, vol. 10, no. 73, pp. 16646-16653, 2011.

[155] M. Srinivasan, A. R. Sudheer, and V. P. Menon, "Ferulic acid: therapeutic potential through its antioxidant property," Journal of Clinical Biochemistry and Nutrition, vol. 40, no. 2, pp. 92-100, 2007.

[156] L. Rondini, M.-N. Peyrat-Maillard, A. Marsset-Baglieri et al., "Bound ferulic acid from bran is more bioavailable than the free compound in rat," Journal of Agricultural and Food Chemistry, vol. 52, no. 13, pp. 4338-4343, 2004.

[157] F. Grases, A. Costa-Bauza, J. Perelló et al., "Influence of concomitant food intake on the excretion of orally administered myo-inositol hexaphosphate in humans," Journal of Medicinal Food, vol. 9, no. 1, pp. 72-76, 2006.

[158] F. Grases, B. M. Simonet, R. M. Prieto, and J. G. March, "Phytate levels in diverse rat tissues: influence of dietary phytate," British Journal of Nutrition, vol. 86, no. 2, pp. 225-231, 2001.

[159] M. Lüchtenborg, M. P. Weijenberg, P. A. Wark et al., "Mutations in APC, CTNNB1 and K-ras genes and expression of hMLH1 in sporadic colorectal carcinomas from the Netherlands cohort study," BMC Cancer, vol. 5, article 160, 2005.

[160] L. Thorstensen, G. E. Lind, T. Løvig et al., "Genetic and epigenetic changes of components affecting the WNT pathway in colorectal carcinomas stratified by microsatellite instability," Neoplasia, vol. 7, no. 2, pp. 99-108, 2005.

[161] V. Johnson, E. Volikos, S. E. Halford et al., "Exon $3 \beta$-catenin mutations are specifically associated with colorectal carcinomas in hereditary non-polyposis colorectal cancer syndrome," Gut, vol. 54, no. 2, pp. 264-267, 2005.

[162] P. Polakis, “The many ways of Wnt in cancer," Current Opinion in Genetics and Development, vol. 17, no. 1, pp. 45-51, 2007.

[163] A. Stanczak, R. Stec, L. Bodnar et al., "Prognostic significance of Wnt-1, $\beta$-catenin and E-cadherin expression in advanced colorectal carcinoma," Pathology and Oncology Research, vol. 17, no. 4, pp. 955-963, 2011.

[164] V. S. W. Li, S. S. Ng, P. J. Boersema et al., "Wnt signaling through inhibition of $\beta$-catenin degradation in an intact Axinl complex," Cell, vol. 149, no. 6, pp. 1245-1256, 2012.

[165] O. Tetsu and F. McCormick, " $\beta$-catenin regulates expression of cyclin D1 in colon carcinoma cells," Nature, vol. 398, no. 6726, pp. 422-426, 1999.

[166] T. Zhang, L. B. Nanney, C. Luongo et al., "Concurrent overexpression of cyclin D1 and cyclin-dependent kinase $4(\mathrm{Cdk} 4)$ in intestinal adenomas from multiple intestinal neoplasia (min) mice and human familial adenomatous polyposis patients," Cancer Research, vol. 57, no. 1, pp. 169-175, 1997.

[167] T.-C. He, A. B. Sparks, C. Rago et al., "Identification of c-MYC as a target of the APC pathway," Science, vol. 281, no. 5382, pp. 1509-1512, 1998.

[168] V. Leardkamolkarn, W. Thongthep, P. Suttiarporn, R. Kongkachuichai, S. Wongpornchai, and A. Wanavijitr, "Chemopreventive properties of the bran extracted from a newly-developed Thai rice: the Riceberry," Food Chemistry, vol. 125, no. 3, pp. 978-985, 2011.

[169] R. Gysin, A. Azzi, and T. Visarius, "Gamma-tocopherol inhibits human cancer cell cycle progression and cell proliferation by down-regulation of cyclins," The FASEB Journal, vol. 16, no. 14, pp. 1952-1954, 2002.

[170] W. Sun, W. Xu, H. Liu et al., " $\gamma$-Tocotrienol induces mitochondria-mediated apoptosis in human gastric adenocarcinoma SGC-7901 cells," The Journal of Nutritional Biochemistry, vol. 20, no. 4, pp. 276-284, 2009.

[171] N. Saad, N. M. Esa, and H. Ithnin, "Suppression of $\beta$-catenin and cyclooxygenase-2 expression and cell proliferation in azoxymethane-induced colonic cancer in rats by rice bran phytic acid (PA)," Asian Pacific Journal of Cancer Prevention, vol. 14, no. 5, pp. 3093-3099, 2013.

[172] D. D. Billadeau, "Primers on molecular pathways: the glycogen synthase kinase-3 $\beta$," Pancreatology, vol. 7, no. 5-6, pp. 398-402, 2007.

[173] A. V. Ougolkov and D. D. Billadeau, "Targeting GSK-3: a promising approach for cancer therapy?" Future Oncology, vol. 2, no. 1, pp. 91-100, 2006.

[174] M. D. Vesely, M. H. Kershaw, R. D. Schreiber, and M. J. Smyth, "Natural innate and adaptive immunity to cancer," Annual Review of Immunology, vol. 29, pp. 235-271, 2011.

[175] E. Pikarsky, R. M. Porat, I. Stein et al., "NF- $\kappa$ B functions as a tumour promoter in inflammation-associated cancer," Nature, vol. 431, no. 7007, pp. 461-466, 2004.

[176] C. J. van der Woude, J. H. Kleibeuker, P. L. M. Jansen, and H. Moshage, "Chronic inflammation, apoptosis and (pre)malignant lesions in the gastro-intestinal tract," Apoptosis, vol. 9, no. 2, pp. 123-130, 2004.

[177] A. J. Henderson, A. Kumar, B. Barnett, S. W. Dow, and E. P. Ryan, "Consumption of rice bran increases mucosal immunoglobulin A concentrations and numbers of intestinal Lactobacillus spp.", Journal of Medicinal Food, vol. 15, no. 5, pp. 469-475, 2012.

[178] A. Murakami, Y. Nakamura, K. Koshimizu et al., "FA15, a hydrophobic derivative of ferulic acid, suppresses inflammatory responses and skin tumor promotion: comparison with ferulic acid," Cancer Letters, vol. 180, no. 2, pp. 121-129, 2002.

[179] S. Morel, A. Didierlaurent, P. Bourguignon et al., "Adjuvant System AS03 containing $\alpha$-tocopherol modulates innate immune response and leads to improved adaptive immunity," Vaccine, vol. 29, no. 13, pp. 2461-2473, 2011.

[180] L. A. Boxer, "Regulation of phagocyte function by alphatocopherol," Proceedings of the Nutrition Society, vol. 45, no. 3, pp. 333-344, 1986.

[181] H. Sakurai, M.-K. Choo, A. Chino et al., "Antimetastatic and immunostimulatory properties of fermented brown rice," Journal of Traditional Medicine, vol. 23, no. 3, pp. 112-116, 2006.

[182] S. Sierra, F. Lara-Villoslada, M. Olivares, J. Jiménez, J. Boza, and J. Xaus, "Increased immune response in mice consuming rice bran oil," European Journal of Nutrition, vol. 44, no. 8, pp. 509516, 2005.

[183] D. Cholujova, J. Jakubikova, and J. Sedlak, "BioBran-augmented maturation of human monocyte-derived dendritic cells," Neoplasma, vol. 56, no. 2, pp. 89-95, 2009.

[184] N. K. B. El-Din, E. Noaman, and M. Ghoneum, "In vivo tumor inhibitory effects of nutritional rice bran supplement MGN3/Biobran on Ehrlich carcinoma-bearing mice," Nutrition and Cancer, vol. 60, no. 2, pp. 235-244, 2008.

[185] S. P. Choi, S. P. Kim, M. Y. Kang, S. H. Nam, and M. Friedman, "Protective effects of black rice bran against chemically-induced inflammation of mouse skin," Journal of Agricultural and Food Chemistry, vol. 58, no. 18, pp. 10007-10015, 2010. 
[186] Z. Xu and J. S. Godber, "Purification and identification of components of $\gamma$-oryzanol in rice bran oil," Journal of Agricultural and Food Chemistry, vol. 47, no. 7, pp. 2724-2728, 1999.

[187] B. J. Lloyd, T. J. Siebenmorgen, and K. W. Beers, "Effects of commercial processing on antioxidants in rice bran," Cereal Chemistry, vol. 77, no. 5, pp. 551-555, 2000.

[188] M. S. Islam, T. Murata, M. Fujisawa et al., "Anti-inflammatory effects of phytosteryl ferulates in colitis induced by dextran sulphate sodium in mice," British Journal of Pharmacology, vol. 154, no. 4, pp. 812-824, 2008.

[189] S. Islam, R. Nagasaka, K. Ohara et al., "Biological abilities of rice bran-derived antioxidant phytochemicals for medical therapy," Current Topics in Medicinal Chemistry, vol. 11, no. 14, pp. 18471853, 2011.

[190] M. Ghoneum, "Enhancement of human natural killer cell activity by modified arabinoxylane from rice bran (MGN-3)," International Journal of Immunotherapy, vol. 14, no. 2, pp. 8999, 1998.

[191] M. Ghoneum and S. Abedi, "Enhancement of natural killer cell activity of aged mice by modified arabinoxylan rice bran (MGN-3/Biobran)," Journal of Pharmacy and Pharmacology, vol. 56, no. 12, pp. 1581-1588, 2004.

[192] M. Ghoneum and J. Brown, "NK immunorestoration of cancer patients by MGN-3, a modified arabinoxylan rice bran (study of 32 patients followed for up to 4 years)," in Anti-Aging Medical Therapeutics, R. M. Klatz and R. Goldman, Eds., pp. 217-226, Health Quest Publications, Marina del Rey, Calif, USA, 1999.

[193] M. Ghoneum and A. Jewett, "Production of tumor necrosis factor- $\alpha$ and interferon- $\gamma$ from human peripheral blood lymphocytes by MGN-3, a modified arabinoxylan from rice bran, and its synergy with interleukin-2 in vitro," Cancer Detection and Prevention, vol. 24, no. 4, pp. 314-324, 2000.

[194] M. Ghoneum and M. Matsuura, "Augmentation of macrophage phagocytosis by modified arabinoxylan rice bran (MGN3/Biobran)," International Journal of Immunopathology and Pharmacology, vol. 17, no. 3, pp. 283-292, 2004.

[195] S.-T. Huang, C.-T. Chen, K.-T. Chieng et al., "Inhibitory effects of a rice hull constituent on tumor necrosis factor $\alpha$, prostaglandin $\mathrm{E} 2$, and cyclooxygenase-2 production in lipopolysaccharide-activated mouse macrophages," Annals of the New York Academy of Sciences, vol. 1042, pp. 387-395, 2005.

[196] B. L. Tan, M. E. Norhaizan, K. Huynh, S. K. Yeap, H. Hazilawati, and K. Roselina, "Brewers' rice modulates oxidative stress in azoxymethane-mediated colon carcinogenesis in rats," World Journal of Gastroenterology, vol. 21, no. 29, pp. 8826-8835, 2015.

[197] Q. Shi, Q. Xiong, B. Wang, X. Le, N. A. Khan, and K. Xie, "Influence of nitric oxide synthase II gene disruption on tumor growth and metastasis," Cancer Research, vol. 60, no. 10, pp. 2579-2583, 2000.

[198] B. L. Tan, M. E. Norhaizan, I. Hairuszah, H. Hazilawati, and K. Roselina, "Brewers' rice: a by-product from rice processing provides natural hepatorenal protection in azoxymethaneinduced oxidative stress in rats," Oxidative Medicine and Cellular Longevity, vol. 2015, Article ID 539798, 10 pages, 2015.

[199] M. M. Manson, "Cancer prevention-the potential for diet to modulate molecular signalling," Trends in Molecular Medicine, vol. 9, no. 1, pp. 11-18, 2003.

[200] V. Calabrese, S. Calafato, E. Puleo et al., "Redox regulation of cellular stress response by ferulic acid ethyl ester in human dermal fibroblasts: role of vitagenes," Clinics in Dermatology, vol. 26, no. 4, pp. 358-363, 2008.
[201] E. Noaman, N. K. Badr El-Din, M. A. Bibars, A. A. Abou Mossallam, and M. Ghoneum, "Antioxidant potential by arabinoxylan rice bran, MGN-3/biobran, represents a mechanism for its oncostatic effect against murine solid Ehrlich carcinoma," Cancer Letters, vol. 268, no. 2, pp. 348-359, 2008. 


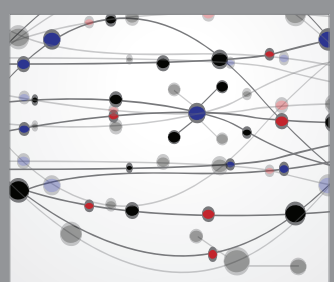

The Scientific World Journal
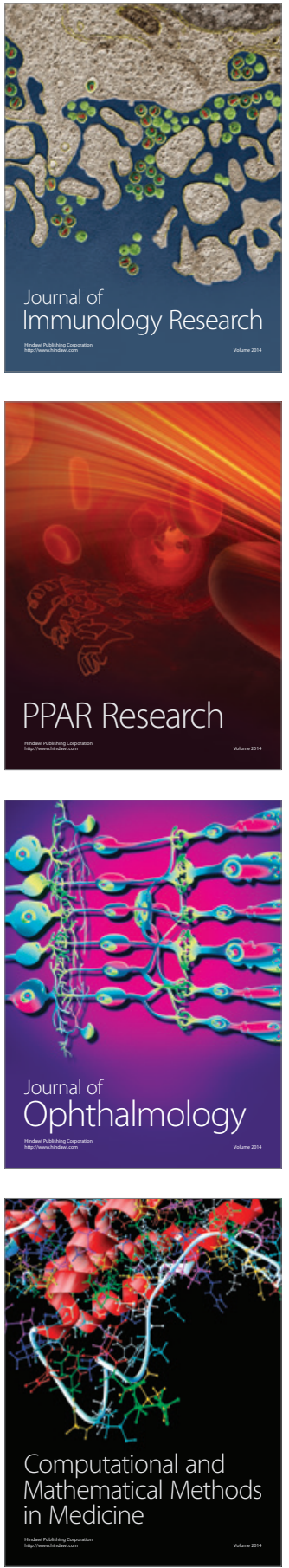

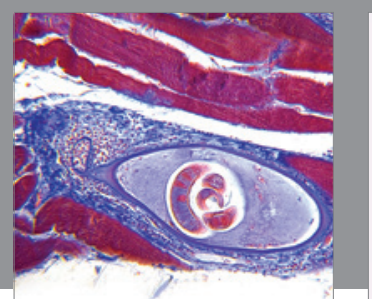

Gastroenterology Research and Practice
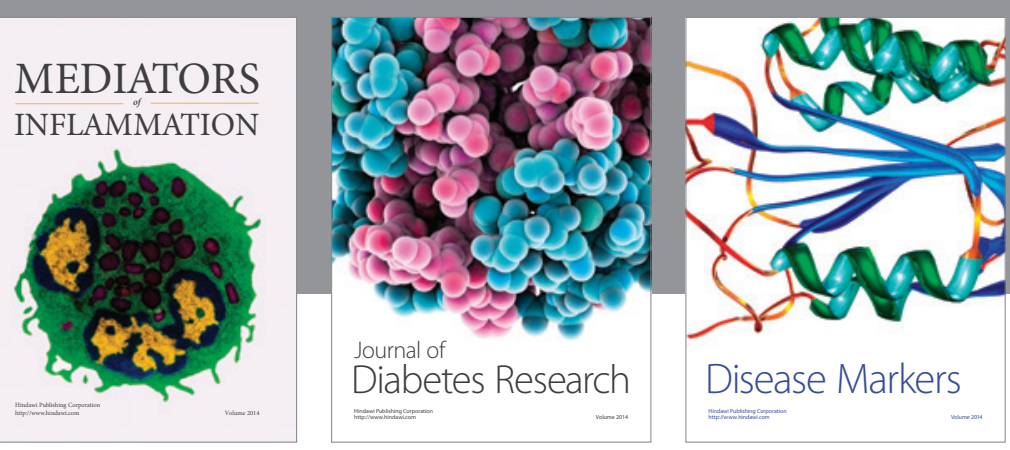

Disease Markers

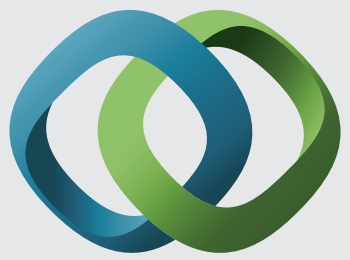

\section{Hindawi}

Submit your manuscripts at

https://www.hindawi.com
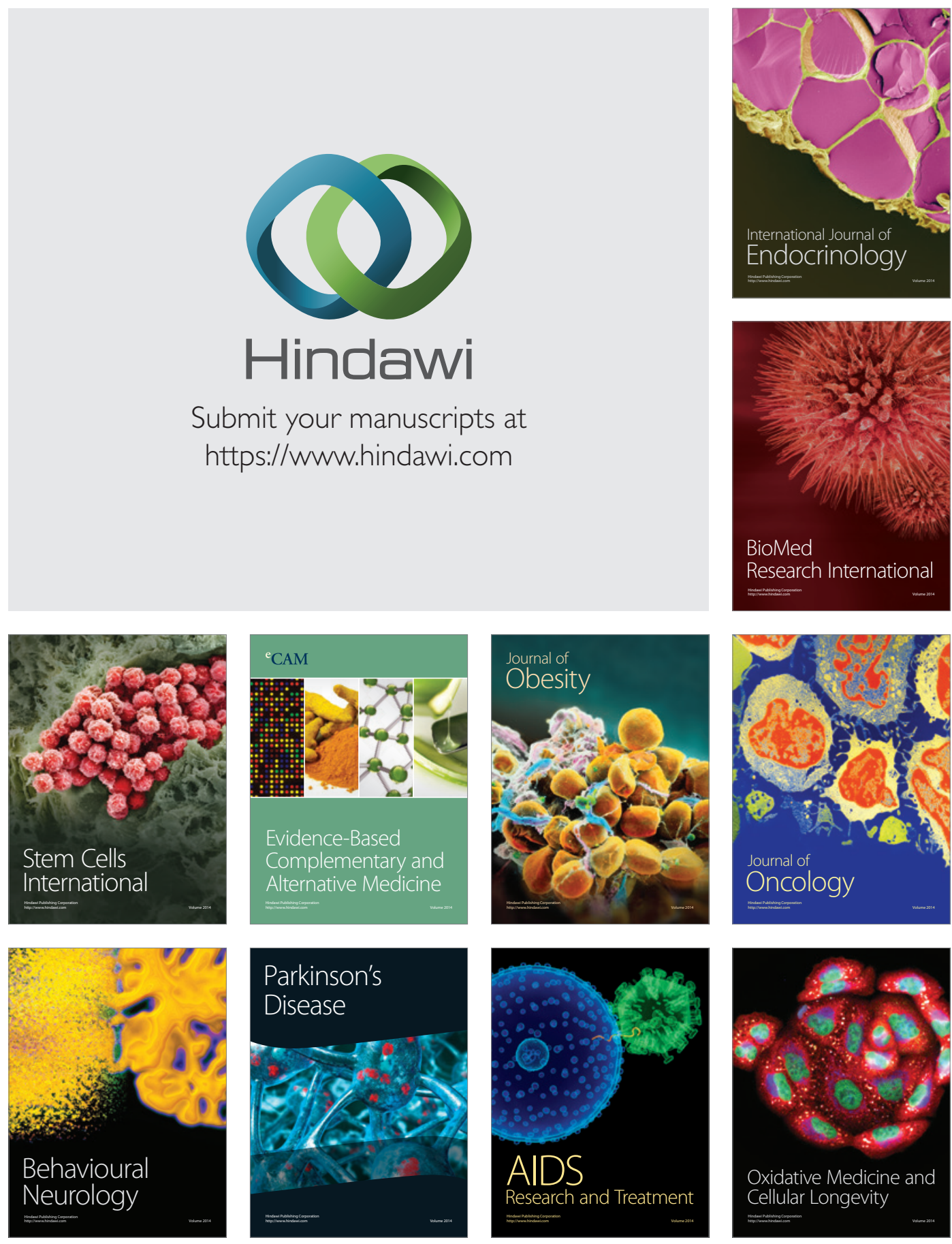